\title{
Variations in airborne bacterial communities at high altitudes over the Noto Peninsula (Japan) in response to Asian dust events
}

\author{
Teruya Maki ${ }^{1}$, Kazutaka Hara ${ }^{2}$, Ayumu Iwata ${ }^{3}$, Kevin C. Lee ${ }^{4}$, Kei Kawai ${ }^{5}$, Kenji Kai ${ }^{5}$, Fumihisa Kobayashi ${ }^{6}$, \\ Stephen B. Pointing ${ }^{4,7}$, Stephen Archer ${ }^{4}$, Hiroshi Hasegawa ${ }^{1}$, and Yasunobu Iwasaka ${ }^{8}$ \\ ${ }^{1}$ College of Science and Engineering, Kanazawa University, Kakuma, Kanazawa, Ishikawa, 920-1192, Japan \\ ${ }^{2}$ National Institute for Environmental Studies, Tsukuba, Ibaraki 305-8506, Japan \\ ${ }^{3}$ Graduate school of Natural Science and Technology, Kanazawa University, Kakuma, Ishikawa, 920-1192, Japan \\ ${ }^{4}$ School of Science, Auckland University of Technology, Private Bag 92006, Auckland 1142, New Zealand \\ ${ }^{5}$ Graduate School of Environmental Studies, Nagoya University, Furocho, Chikusaku, Nagoya, 464-8601, Japan \\ ${ }^{6}$ Graduate School of Science and Technology, Hirosaki University, Bunkyo-cho 3, Hirosaki, Aomori, 036-8561, Japan \\ ${ }^{7}$ Yale-NUS College, National University of Singapore, 10 College Avenue West, Saga-RC1 01-05C, 138609, Singapore \\ ${ }^{8}$ Community Research Service Group, University of Shiga Prefecture, 2500 Yasakamachi, Hikoneshi, Shiga, 522-8533, Japan
}

Correspondence to: Teruya Maki (makiteru@se.kanazawa-u.ac.jp)

Received: 5 December 2016 - Discussion started: 25 January 2017

Revised: 29 August 2017 - Accepted: 31 August 2017 - Published: 9 October 2017

\begin{abstract}
Aerosol particles, including airborne microorganisms, are transported through the free troposphere from the Asian continental area to the downwind area in East Asia and can influence climate changes, ecosystem dynamics, and human health. However, the variations present in airborne bacterial communities in the free troposphere over downwind areas are poorly understood, and there are few studies that provide an in-depth examination of the effects of long-range transport of aerosols (natural and anthropogenic particles) on bacterial variations. In this study, the vertical distributions of airborne bacterial communities at high altitudes were investigated and the bacterial variations were compared between dust events and non-dust events.

Aerosols were collected at three altitudes from ground level to the free troposphere (upper level: 3000 or $2500 \mathrm{~m}$; middle level: 1200 or $500 \mathrm{~m}$; and low level: $10 \mathrm{~m}$ ) during Asian dust events and non-dust events over the Noto Peninsula, Japan, where westerly winds carry aerosols from the Asian continental areas. During Asian dust events, air masses at high altitudes were transported from the Asian continental area by westerly winds, and laser imaging detection and ranging (lidar) data indicated high concentrations of nonspherical particles, suggesting that dust-sand particles were transported from the central desert regions of Asia. The air samples collected during the dust events contained 10-100
\end{abstract}

times higher concentrations of microscopic fluorescent particles and optical particle counter (OPC) measured particles than in non-dust events. The air masses of non-dust events contained lower amounts of dust-sand particles. Additionally, some air samples showed relatively high levels of black carbon, which were likely transported from the Asian continental coasts. Moreover, during the dust events, microbial particles at altitudes of $>1200 \mathrm{~m}$ increased to the concentrations ranging from $1.2 \times 10^{6}$ to $6.6 \times 10^{6}$ particles $\mathrm{m}^{-3}$. In contrast, when dust events disappeared, the microbial particles at $>1200 \mathrm{~m}$ decreased slightly to microbial-particle concentrations ranging from $6.4 \times 10^{4}$ to $8.9 \times 10^{5}$ particles $\mathrm{m}^{-3}$.

High-throughput sequencing technology targeting $16 \mathrm{~S}$ rRNA genes (16S rDNA) revealed that the bacterial communities collected at high altitudes (from 500 to $3000 \mathrm{~m}$ ) during dust events exhibited higher diversities and were predominantly composed of natural-sand/terrestrial bacteria, such as Bacillus members. During non-dust periods, airborne bacteria at high altitudes were mainly composed of anthropogenic/terrestrial bacteria (Actinobacteria), marine bacteria (Cyanobacteria and Alphaproteobacteria), and plantassociated bacteria (Gammaproteobacteria), which shifted in composition in correspondence with the origins of the air masses and the meteorological conditions. The airborne bacterial structures at high altitudes suggested remarkable 
changes in response to air mass sources, which contributed to the increases in community richness and to the domination of a few bacterial taxa.

\section{Introduction}

Airborne microorganisms (bioaerosols) associated with desert-sand and anthropogenic particles were transported through free troposphere from the Asian continents to downwind regions of East Asia and can influence climate changes, ecosystem dynamics, and human health (Iwasaka et al., 2009). Natural dust events from the Asian desert regions carry airborne microorganisms, supporting atmospheric microbial dispersals (Griffin, 2007; Maki et al., 2010; Pointing and Belnap, 2014). Haze days caused by anthropogenic particles from Asian continents also affect airborne microbial abundance and endotoxin levels (Wei et al., 2016). Some studies demonstrated that Asian dust events, including natural and anthropogenic particles, cause vertical mixture of bioaerosols in downwind areas, such as Japan (Huang et al., 2015b; Sugimoto et al., 2012; Maki et al., 2015).

Bioaerosols, which include bacteria, fungi, and viruses, are transported from ground environments to the free troposphere and account for a substantial proportion of organic aerosols (Jaenicke, 2005). Bioaerosols are thought to influence atmospheric processes by participating in atmospheric chemical reactions and in the formation of cloudnucleating particles (Pratt et al., 2009; Morris et al., 2011; Hara et al., 2016b). Indeed, airborne microorganisms act as ice nuclei that are related to ice-cloud formation processes (Möhler et al., 2007; Delort et al., 2010; Creamean et al., 2013; Joly et al., 2013). In particular, ice-nucleation activating proteins of some microorganisms, such as Pseudomonas syringae, Xanthomonas campestris, and Erwinia herbicola, exhibit high nucleation activities, initiating ice formation at relatively warm temperatures (greater than $-5^{\circ} \mathrm{C}$ ) (Morris et al., 2004) in comparison to the inorganic ice-nucleating particles, such as potassium feldspar (approximately $-8^{\circ} \mathrm{C}$ ) (Atkinson et al., 2013). Ice-nucleating particles that originate from bioaerosols are believed to activate ice formation more efficiently than inorganic substances (Hoose and Möhler, 2012; Murray et al., 2012) and are primary contributors of rapid ice-cloud formation even at low concentrations in the clouds at temperatures between -8 and $-3{ }^{\circ} \mathrm{C}$ (Hallett and Mossop, 1974). Bioaerosols are key factors for elucidating the detailed mechanisms of ice-cloud formation and precipitation over East Asia (Hara et al., 2016a, b), but the microbial characteristics of bioaerosols transported over long distances by Asian dust events are still unclear. Furthermore, the microorganisms transported by Asian dust events increase the allergenic burden, consequently inducing asthma incidences (Ichinose et al., 2005) and contributing to the dispersal of diseases such as Kawasaki disease (Rodó et al., 2011) and rust diseases (Brown and Hovmøller, 2002).
In downwind areas of East Asia, the atmospheric bacterial dynamics at high altitudes should be investigated in order to understand the ecological and meteorological influences of airborne bacteria as well as their long-range dispersion. Meteorological shifts and dust events can dramatically alter airborne bacterial communities at high altitudes in Japan (Maki et al., 2013, 2015) because of air masses that originate from heterogeneous environments, including marine, mountainous, urban, and desert areas. The airborne microorganisms around North American mountains $(2700 \mathrm{~m}$ above sea level) were also found to increase their species diversities in response to Asian dust events (Smith et al., 2013). Highthroughput sequencing technology can generate large numbers of nucleotide sequences and the sequencing database has played an important role for investigation of airborne bacterial compositions (Brodie et al., 2007; Woo et al., 2013). Indeed, the analyses using high-throughput sequencing has demonstrated that airborne bacterial populations at ground levels change in response to pollutants from Beijing (Cao et al., 2014) and African dust events (Mazar et al., 2016). To investigate their long-range transported bacteria while avoiding the ground-surface contaminations, the bioaerosol samples collected at high altitudes by aircrafts were analysed using high-throughput sequencing, showing the airborne microbial diversities at high altitudes, ranging from 1000 to $3000 \mathrm{~m}$ (DeLeon-Rodriguez et al., 2013; Maki et al., 2015). There are also a few studies on the vertical bacterial distribution from the ground level to the troposphere (DeLeonRodriguez et al., 2013; Maki et al., 2015). Nonetheless, while some variations were observed, the specific changes in tropospheric bioaerosols over East Asia, and, in particular, differences between Asian dust and non-dust events remain poorly understood.

Organic aerosol particles, such as bioaerosols, account for high rates of tropospheric aerosols, ranging from 30 to $80 \%$ (Jaenicke, 2005), and fluctuate at high concentrations, ranging from $10^{3}$ to $10^{5}$ particles $\mathrm{m}^{-3}$, under the boundary layer at $4000 \mathrm{~m}$ above the ground (Twohy et al., 2016). Epifluorescence microscopy using fluorescent-dye staining is a useful tool for observation and determination of microbial particles in the atmosphere, demonstrating that the biomass of airborne microorganisms increased 10- to 100fold during Asian dust events (Hara et al., 2012; Maki et al., 2014). Under a fluorescence microscope, DNA in microbial particles fluoresce blue when stained with 4, 6-diamidino2-phenylindole (DAPI) (Russell et al., 1974), and organic materials aggregated with proteins and microbial cell components were confirmed as yellow fluorescence particles (Mostajir et al., 1995). Mineral particles (white particles) and black carbon (black particles) can also be observed as background fluorescence in microscopic observation fields (Maki et al., 2014). Accordingly, several DAPI-stained particles could be detected in air samples collected from all over Japan during dust events (Maki et al., 2013) and can be 


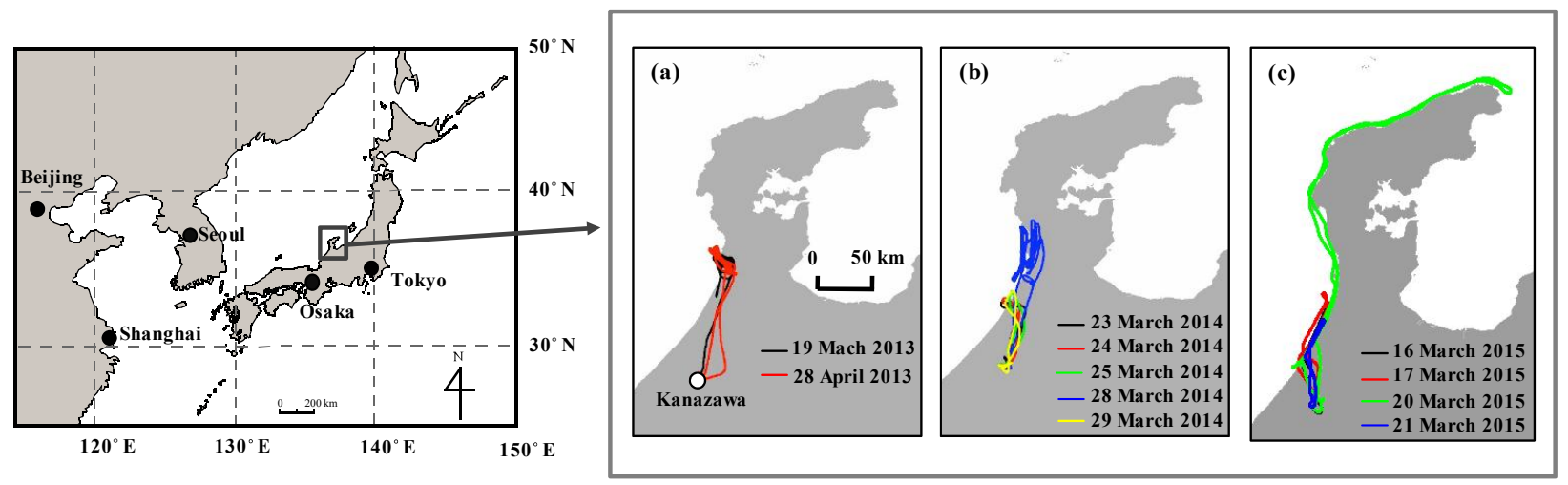

Figure 1. Sampling location and helicopter flight routes during the sampling periods on (a) 19 March and 28 April 2013; (b) 23, 24, 25, and 29 March 2014; and (c) 16, 17, 20, and 21 March 2015.

used as indicators for evaluating the amounts of some aerosol species during dust events.

In this study, the bacterial communities from different altitudes around the Japanese islands were compared to identify the potential influences of long-range transported air masses on tropospheric bacteria. We used a helicopter for collecting air samples at altitudes ranging from 1200 to $3000 \mathrm{~m}$ over the Noto Peninsula, Japan. Helicopter sampling was used to collect chemical components at high altitudes, which has previously been used to avoid contamination from the downwash created by spinning rotors (Watanabe et al., 2016). This airsampling method can directly collect aerosols moving from Asian continents or marine areas to Japan. We estimated the air mass conditions using the meteorological data obtained during the sampling periods and determined aerosol amounts by using meteorological monitoring and epifluorescence microscopic observation. Bacterial community structures were analysed by using high-throughput sequencing targeting bacterial 16S rRNA genes (16S rDNA).

\section{Experiments}

\subsection{Sampling}

Aerosol sampling using a helicopter (R44; Robinson, CA, USA) was performed over coastal areas from Uchinada $\left(36^{\circ} 67 \mathrm{~N}, 136^{\circ} 64 \mathrm{E}\right)$ to Hakui $\left(36^{\circ} 92 \mathrm{~N}, 136^{\circ} 76 \mathrm{E}\right)$ in the Noto Peninsula, Japan. Both cities are located on the western coast of the Noto Peninsula where aerosols arrive from continental areas across the Sea of Japan and are mixed with local aerosols (Fig. 1). The helicopter traversed $20 \mathrm{~km}$ northwest from Kanazawa to Uchinada; air sampling was continuously conducted from Uchinada to the northern coastal areas. To compare the vertical distributions of airborne bacteria during dust and non-dust events, air samples were collected using a helicopter at the 1 to 3 altitudes ranging from 500 to $3000 \mathrm{~m}$ above ground level (a.g.l., Table 1). Air samples from low-altitude regions $(10 \mathrm{~m}$ a.g.l.) were collected from the roof of a building located at Taki bay in Hakui $\left(36^{\circ} 92 \mathrm{~N}\right.$, $\left.136^{\circ} 76 \mathrm{E}\right)$. To compare the vertical bacterial distribution, aerosol samples were collected during the daytime (from 09:00 Japanese standard time (JST; UTC $+9 \mathrm{~h}$ ) to 16:30 JST) on 19 March 2013, 28 April 2013, 28 March 2014, and 20 March 2015. These samples were collected at the following altitude sets; (1) 2500, 1200, and $10 \mathrm{~m}$; (2) 3000, 1200, and $10 \mathrm{~m}$; (3) 3000, 1200, and $10 \mathrm{~m}$; and (4) 2500 and $500 \mathrm{~m}$ and samples were labelled as shown in Table 1. To investigate the bacterial changes at altitudes in response to time, temporal transect at the altitude of $1200 \mathrm{~m}$ was prepared for 7 days - 23, 24, 25, and 29 March 2014 and 16, 17, and 21 March 2015 - and the sample names are showed in Table 1.

Air samples were collected through sterilized polycarbonate filters $(0.22 \mu \mathrm{m}$ pore size; Whatman, Tokyo, Japan) with sterilized filter holders (Swinnex filter holder; Merck, Darmstadt, German) connected to an air pump. At the sterilization processes, the filters and the filter-holder parts were irradiated separately under UV light for $1.0 \mathrm{~h}$ and the filter holders attached with the filters were autoclaved at $121^{\circ} \mathrm{C}$ for $20 \mathrm{~min}$. Air sampling was performed with a flow rates of $5 \mathrm{~L} \mathrm{~min}^{-1}$ over sampling periods from 0.2 to $1.0 \mathrm{~h}$. Triplicate sampling filters were obtained for each altitude. During helicopter sampling, outside air was transferred from a window to the bioaerosol-sampling inlet, which was sterilized by autoclaving and UV irradiation. The sterilized filter holders were inserted into the sampling inlet to avoid contamination. To collect air particles at an altitude of $10 \mathrm{~m}$, we used filter holders fixed on a $3 \mathrm{~m}$ stick, which was placed on the roof of a building (Maki et al., 2014).

In total, 18 air samples were obtained during the sampling periods (Table 1). Of the two filters used to collect each sample, one filter was used to determine the particulate abundances under fluorescence microscopy and the other was stored at $-80^{\circ} \mathrm{C}$ before the extraction of genomic DNA (gDNA) for analysis of bacterial compositions. 
Table 1. Sampling information during the sampling periods.

\begin{tabular}{|c|c|c|c|c|c|c|c|c|c|}
\hline $\begin{array}{l}\text { Sample } \\
\text { name }\end{array}$ & $\begin{array}{l}\text { Sampling } \\
\text { date }\end{array}$ & $\begin{array}{l}\text { Collection } \\
\text { time (JST) }\end{array}$ & $\begin{array}{l}\text { Total } \\
\text { time } \\
(\mathrm{min})\end{array}$ & $\begin{array}{r}\text { Air } \\
\text { volume }\end{array}$ & $\begin{array}{l}\text { Sampling } \\
\text { method }\end{array}$ & $\begin{array}{l}\text { Sampling } \\
\text { location } 1\end{array}$ & $\begin{array}{l}\text { Free } \\
\text { troposphere }^{2}\end{array}$ & $\begin{array}{l}\text { Dust event } \\
\text { day }^{3}\end{array}$ & $\begin{array}{l}\text { Dust } \\
\text { influence }^{4}\end{array}$ \\
\hline 13H319-u & 19 March 2013 & $14: 04-15: 04$ & 60 & $700 \mathrm{~L}$ & helicopter & $2500 \mathrm{~m}$ & FT & + & dust sample \\
\hline 13H319-m & & $15: 19-16: 19$ & 60 & $700 \mathrm{~L}$ & helicopter & $1200 \mathrm{~m}$ & $\mathrm{ABL}$ & + & non-dust sample \\
\hline 13H319-1 & & $14: 25-15: 25$ & 60 & $700 \mathrm{~L}$ & building & $10 \mathrm{~m}$ & GL & + & non-dust sample \\
\hline 13H428-u & 28 April 2013 & $12: 10-13: 04$ & 56 & $653 \mathrm{~L}$ & helicopter & $2500 \mathrm{~m}$ & FT & - & non-dust sample \\
\hline 13H428-m & & $13: 13-14: 03$ & 50 & $583 \mathrm{~L}$ & helicopter & $1200 \mathrm{~m}$ & $\mathrm{ABL}$ & - & non-dust sample \\
\hline $13 \mathrm{H} 428-1$ & & $12: 03-13: 03$ & 60 & $700 \mathrm{~L}$ & building & $10 \mathrm{~m}$ & GL & - & non-dust sample \\
\hline 14H328-u & 28 March 2014 & $12: 50-13: 50$ & 60 & $700 \mathrm{~L}$ & helicopter & $3000 \mathrm{~m}$ & FT & - & non-dust sample \\
\hline 14H328-m & & $14: 04-15: 04$ & 60 & $700 \mathrm{~L}$ & helicopter & $1200 \mathrm{~m}$ & $\mathrm{ABL}$ & - & non-dust sample \\
\hline $14 \mathrm{H} 328-1$ & & 13:00-14:00 & 60 & $700 \mathrm{~L}$ & building & $10 \mathrm{~m}$ & GL & - & non-dust sample \\
\hline $15 \mathrm{H} 320-\mathrm{u}$ & 20 March 2015 & $12: 26-13: 23$ & 47 & $548 \mathrm{~L}$ & helicopter & $2500 \mathrm{~m}$ & FT & + & dust sample \\
\hline 15H320-m & & $13: 39-14: 40$ & 60 & $711 \mathrm{~L}$ & helicopter & $500 \mathrm{~m}$ & $\mathrm{ABL}$ & + & dust sample \\
\hline $14 \mathrm{H} 323-\mathrm{m}$ & 23 March 2014 & $10: 45-11: 02$ & 17 & $11.1 \mathrm{~L}$ & helicopter & $1200 \mathrm{~m}$ & $\mathrm{ABL}$ & - & non-dust sample \\
\hline 14H324-m & 24 March 2014 & 09:09-09:30 & 21 & $13.7 \mathrm{~L}$ & helicopter & $1200 \mathrm{~m}$ & $\mathrm{ABL}$ & - & non-dust sample \\
\hline $14 \mathrm{H} 325-\mathrm{m}$ & 25 March 2014 & $09: 31-09: 50$ & 29 & $18.9 \mathrm{~L}$ & helicopter & $1200 \mathrm{~m}$ & $\mathrm{ABL}$ & - & non-dust sample \\
\hline 14H328-m & 28 March 2014 & 14:04-15:04 & 60 & $700 \mathrm{~L}$ & helicopter & $1200 \mathrm{~m}$ & $\mathrm{ABL}$ & - & non-dust sample \\
\hline 14H329-m & 29 March 2014 & 09:06-09:24 & 15 & $9.75 \mathrm{~L}$ & helicopter & $1200 \mathrm{~m}$ & $\mathrm{PT}$ & - & non-dust sample \\
\hline 15H316-m & 16 March 2015 & $11: 21-11: 43$ & 22 & $14.3 \mathrm{~L}$ & helicopter & $1200 \mathrm{~m}$ & FT & + & dust sample \\
\hline 15H317-m & 17 March 2015 & 11:04-11:31 & 27 & $17.6 \mathrm{~L}$ & helicopter & $1200 \mathrm{~m}$ & FT & + & dust sample \\
\hline $15 \mathrm{H} 320-\mathrm{u}$ & 20 March 2015 & $12: 26-13: 23$ & 47 & $548 \mathrm{~L}$ & helicopter & $2500 \mathrm{~m}$ & FT & + & dust sample \\
\hline $15 \mathrm{H} 321-\mathrm{m}$ & 21 March 2015 & $15: 35-15: 55$ & 20 & $13.0 \mathrm{~L}$ & helicopter & $1200 \mathrm{~m}$ & FT & + & dust sample \\
\hline
\end{tabular}

${ }^{1}$ Height above the ground. ${ }^{2}$ Free troposphere: FT; atmospheric boundary layer: ABL; phase transitions: PT; GL: ground level. ${ }^{3}$ The occurrences of dust events are evaluated by depending on lidar data or trajectories. Dust-event day: +; non-dust-event day: - ${ }^{4}$ The air sample including dust particle (dust sample) or that without dust particles (non-dust sample) are identified via microscopic observation.

\subsection{Characteristics and trajectories of air masses}

Information regarding weather conditions (temperature, relative humidity, and pressure) was gathered. During the helicopter flight, outside air was transferred from a window into the meteorological-measurement inlet, into which the adaptor of the measurement device (TR-73U; T\&D Corporation, Matsumoto, Japan) was inserted, and the temperature, relative humidity, and pressures were sequentially measured. The temperature and relative humidity at an altitude of $10 \mathrm{~m}$ were also measured on the roof of a building in Hakui. The depolarization ratio, which was measured by laser imaging detection and ranging (lidar) measurements at Toyama, has been used for the detection of non-spherical aerosols, such as mineral dust particles and/or sea salts.

To track the transport pathways of air masses, $72 \mathrm{~h}$ back trajectories were calculated using the National Oceanic and Atmospheric Administration (NOAA) HYbrid Single Particle Lagrangian Integrated Trajectory (HYSPLIT) model (http://www.arl.noaa.gov/HYSPLIT.php). The coordinator of Hakui was used as the back-trajectory starting point at several altitudes from 10 to $3000 \mathrm{~m}$ a.g.l. to estimate the trajectories of the air masses.

\subsection{Determination of particle abundance}

The air particles at each altitude were measured using an optical particle counter (OPC: Rion, Tokyo, Japan). The OPC was connected to the meteorological-measurement inlet. The air particles at an altitude of $10 \mathrm{~m}$ were also counted using the OPC placed on the roof of a building.

Fluorescent particles stained with DAPI were also counted via epifluorescence microscopy. Within $2 \mathrm{~h}$ of sampling, $1 \mathrm{~mL}$ of $1 \%$ paraformaldehyde was added to one of the filters to fix the aerosols. After a $1 \mathrm{~h}$ incubation, the filter was stained with DAPI at a final concentration of $0.5 \mu \mathrm{g} \mathrm{mL}^{-1}$ for 15 min (Russell et al., 1974). Next, the filter was placed on a slide in a drop of low-fluorescence immersion oil (Type-F IMMOIL-F30CC, Olympus, Tokyo, Japan). A second drop of oil was added, and a coverslip was placed on top. Particles on the filter were observed using a fluorescence microscope (BX-51, Olympus, Tokyo, Japan) with a UV excitation system. A filter transect was scanned, and the four categorized particles, including white fluorescent particles, blue fluorescent particles (microbial particles), yellow fluorescent particles, and black particles, on the filter transect were counted using a previously reported observational technique (Maki et al., 2014). The TA connections in DNA sequences of microbial particles are bound with DAPI, emitting clear blue fluorescence. However, the aggregation of organic matter might also accumulate DAPI at high amounts emitting yellow fluorescence, which is due to the formation of a compound with DAPI. Mineral particles often have white autofluorescence or emit weak blue (mostly white) fluorescence originating from residues of DAPI on the particle surfaces and can be iden- 
tified on the weak bright background of microscopic observation fields. The black colour of black carbon can be identified in the background. The detection limit of aerosol particle concentration was $1.1 \times 10^{4}$ particles $\mathrm{m}^{-3}$ of air.

\subsection{Analysis of bacterial community structures using MiSeq sequencing analysis targeting 16S rDNA sequences}

After the aerosol particles on the other two filters were suspended in $3 \mathrm{~mL}$ of sterile $0.6 \% \mathrm{NaCl}$ solution, the particles were pelleted by centrifugation at $20000 \times g$ for $10 \mathrm{~min}$. The gDNA was then extracted from the particle pellets using sodium dodecyl sulfate, proteinase $\mathrm{K}$, and lysozyme and purified by phenol-chloroform extraction as previously described (Maki et al., 2008). The bacterial community structure was determined using MiSeq DNA sequencing, which facilitates multiplexed partial sequencing of $16 \mathrm{~S}$ rDNA. Fragments of $16 \mathrm{~S}$ rDNA (approximately $500 \mathrm{bp}$ ) were amplified from the extracted gDNA by PCR using the universal $16 \mathrm{~S}$ rDNA bacterial primers $515 \mathrm{~F}\left(5^{\prime}-\right.$ Seq A-TGTGCCAGCMGCCGCGGTAA-3') and 806R (5'Seq B-GGACTACHVGGGTWTCTAAT-3') (Caporaso et al., 2011), where Seq A and Seq B represent the nucleotide sequences bounded by the second set of PCR primers described below. The PCR amplicon sequences covered the variable region V4 of the $16 \mathrm{~S}$ rRNA gene. Thermal cycling was performed using a thermocycler (Program Temp Control System PC-700; ASTEC, Fukuoka, Japan) under the following conditions: denaturation at $94{ }^{\circ} \mathrm{C}$ for $1 \mathrm{~min}$, annealing at $52^{\circ} \mathrm{C}$ for $2 \mathrm{~min}$, and extension at $72^{\circ} \mathrm{C}$ for $2 \mathrm{~min}$ for 20 cycles. Fragments of $16 \mathrm{~S}$ rDNA in PCR products were amplified again using the second PCR forward primer $\left(5^{\prime}-\right.$ Adaptor C-Xxxxxxxx-Seq $\left.\mathrm{A}-3^{\prime}\right)$ and reverse primer $\left(5^{\prime}-\right.$ Adaptor D-Seq B-3'), where adaptors C and D were used for the MiSeq sequencing reaction. The sequences "xxxxxxxx" comprise an eight-nucleotide sequence tag designed for sample identification barcoding. Thermal cycling was performed under the following conditions: denaturation at $94^{\circ} \mathrm{C}$ for $1 \mathrm{~min}$, annealing at $59^{\circ} \mathrm{C}$ for $2 \mathrm{~min}$, and extension at $72{ }^{\circ} \mathrm{C}$ for 2 min for 15 cycles. PCR amplicons were purified using the MonoFas DNA purification kit (GL Sciences, Tokyo, Japan). PCR amplicons from each sample were pooled at approximately equal amounts into a single sequencing tube on a MiSeq Genome Sequencer (Illumina, CA, USA) machine. The sequences obtained for each sample were demultiplexed based on the tag, including the eight-nucleotide sequence. After removal of the tags, an average read length of 450 bp was obtained. Negative controls (no template and extraction products from unused filters) were prepared in the DNA extraction process to check for contamination. The amount of gDNA extracted from air samples ranged from the detection limit $\left(<0.5 \mathrm{ng}\right.$ samples $\left.^{-1}\right)$ to approximately $50 \mathrm{ng} \mathrm{samples}^{-1}$ and cannot be determined directly by light absorbance measurements. Accordingly, quantities of gDNA were estimated using the PCR products after the first amplification step and compared with the microbial-particle concentrations that were determined by fluorescence microscopic observation. The efficiency of the gDNA extraction from air samples was more than $80 \%$.

Before the analysis of bacterial community structures, USEARCH v.8.01623 (Edgar, 2013) was used to process the raw Illumina sequencing reads. Anomalous sequences were removed with the following workflow. First, the forward and reverse paired-end reads were merged, and the merged reads with lengths outside of the 200-500 bp range or those exceeding six homopolymers were discarded using Mothur v1.36.1 (Schloss et al., 2009). Next, the sequences were subjected to Q-score filtering to remove reads with more than one expected error. Reads occurring only once in the entire dataset (singleton) were then removed. These sequences were clustered de novo (with a minimum identity of $97 \%$ ) into 204 operational taxonomic units (OTUs) among the 18 samples. The taxonomy of the representative OTU sequences was assigned using the RDP classifier (Wang et al., 2007) implemented in QIME v1.9.1 (Caporaso et al., 2010). Non-metric multidimensional scaling (NMDS) plot of the pairwise Bray-Curtis distance matrix were used for the classification of all air samples. Greengenes release 13_8 (McDonald et al., 2012) was used as the reference taxonomic database.

\subsection{Accession numbers}

All data obtained from MiSeq sequencing data have been deposited in the DDBJ/EMBL/GenBank database (accession number of the submission is PRJEB17915).

\section{Results}

\subsection{Air mass analyses using lidar measurements, back trajectories, and metrological data}

The vertical distributions of the depolarization ratio determined by lidar measurements were assessed for the four sampling events (19 March 2013, 20 March 2015, 28 April 2013, and 28 March 2014). The depolarization ratio increased at the altitude of $3000 \mathrm{~m}$ on 19 March 2013 (Fig. 2a), while it decreased at the middle altitude of $1000 \mathrm{~m}$. The air mass on 20 March 2015 showed high values of depolarization ratio at altitudes of 2500 and $500 \mathrm{~m}$, consistent with the vertical distribution of non-spherical (mineral dust) particles over the Noto Peninsula (Fig. 2d). A 3-day back-trajectory analysis indicated that the air mass at $3000 \mathrm{~m}$ on both sampling dates came from the Asian desert region to the Noto Peninsula (Hakui) immediately across the Sea of Japan (Fig. 3). These results indicated the dust-event occurrence on 19 March 2013 was specific to the upper altitude of $3000 \mathrm{~m}$, while the dust event on 20 March 2015 occurred between the altitudes of 2500 and $500 \mathrm{~m}$. Moreover, samples collected on 
(a)
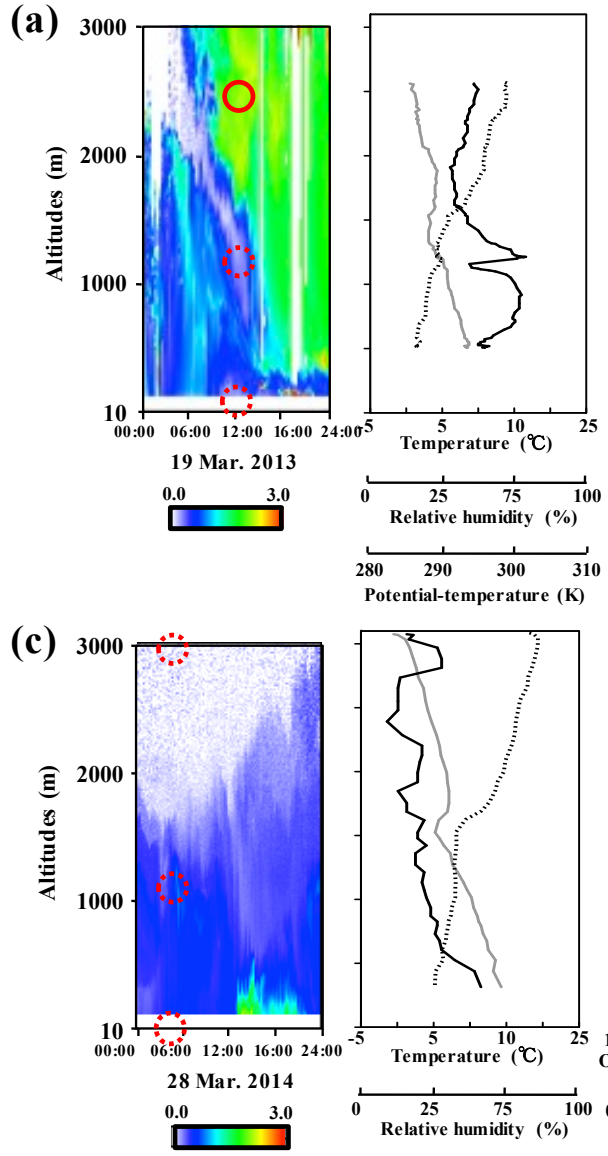
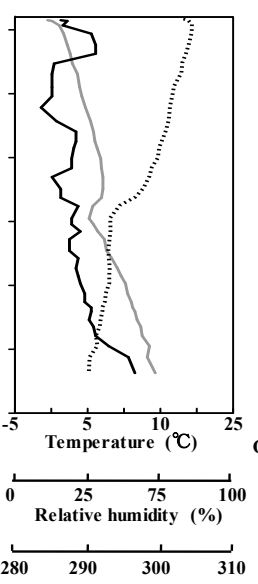

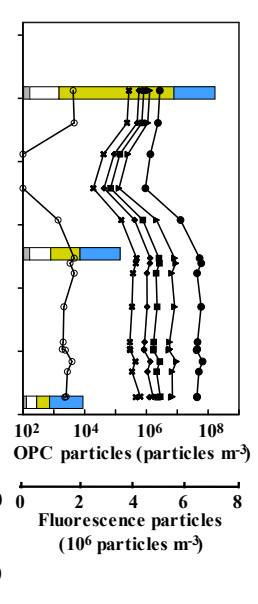

(b)
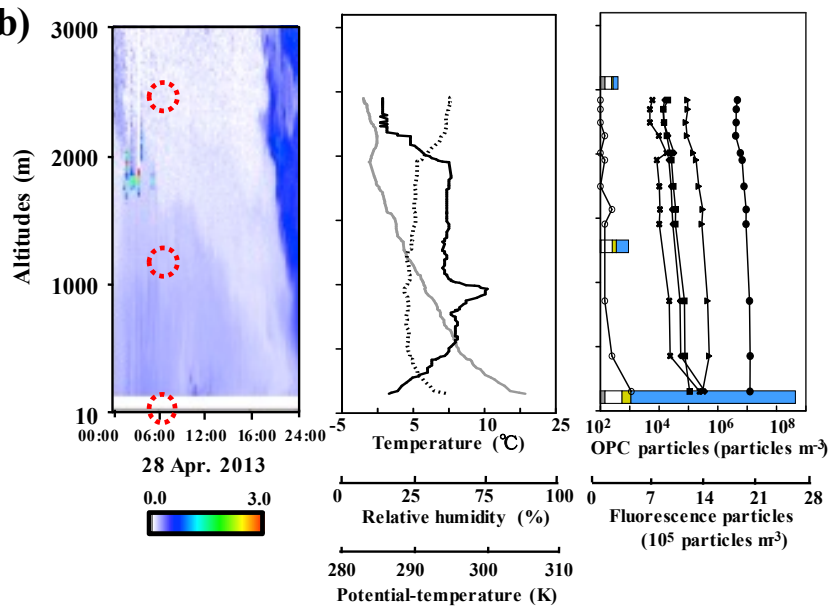

$\left(10^{5}\right.$ particles $\left.\mathrm{m}^{3}\right)$

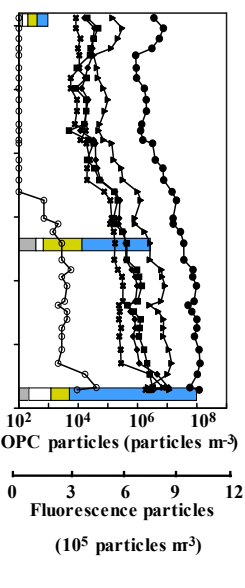

(d)

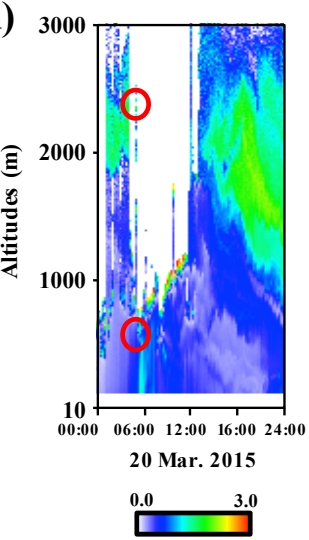

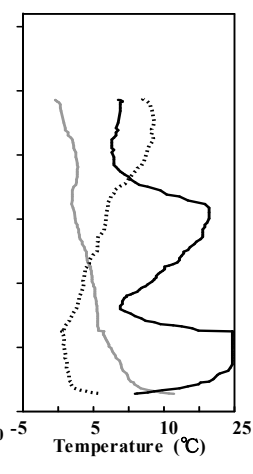
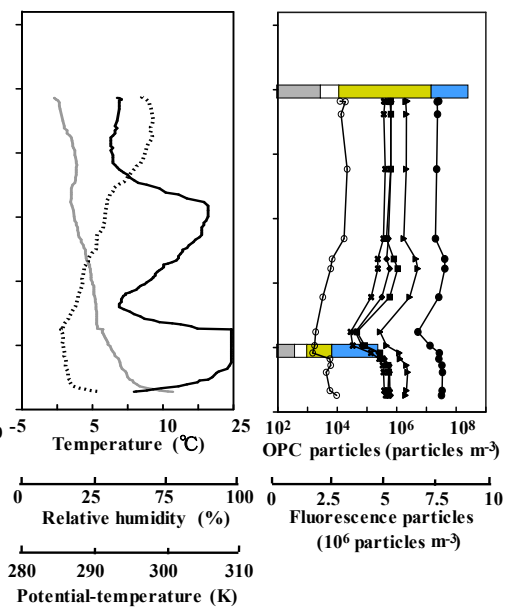

Figure 2. Lidar observation of the depolarization ratio in Toyama city, as well as vertical changes in temperature, relative humidity, and potential temperature and vertical distributions of concentrations of OPC-counted particles and DAPI-stained particles from the four sampling events on 19 March 2013 (a), 28 April 2013 (b), 28 March 2014 (c), and 20 March 2015 (d). The red circles in the lidar images indicate that the sampling air included dust mineral particles (solid line) or that dust-event influences are absent at the altitudes on the sampling time (dotted line). OPC-counted particles were categorized according to diameter sizes of $0.3-0.5 \mu \mathrm{m}$ (closed squares), $0.5-0.7 \mu \mathrm{m}$ (closed triangles), 0.7-1.0 $\mu \mathrm{m}$ (closed circles), 1.0-2.0 $\mu \mathrm{m}$ (closed diamonds), 2.0-5.0 $\mu \mathrm{m}$ (crosses), and > 5.0 $\mu \mathrm{m}$ (open circles). DAPI-stained particles were classified into microbial particles (blue bars), white particles (white bars), yellow fluorescent particles (yellow bars), and black carbon (grey bars).

28 April 2013 and 28 March 2014 exhibited a low depolarization ratio (Fig. 2b-c), and the air masses on these two sampling dates came from areas of North Asia, including eastern Siberia (Fig. 3).

The air-sampling periods from the March 2014 time series (from 23 to 29 March 2014) and the March 2015 time series (from 16 to 21 March 2015) showed different patterns of depolarization ratio and air mass trajectory roots between the two series (Figs. 4 and 5). Depolarization ratio from March 2014 maintained lower values (Fig. 4a) and the trajectory lines changed the roots from eastern Siberia to the Korean Peninsula before surrounding the Japanese islands (Fig. 4c). In contrast, the sampling period during March 2015 had substantially higher depolarization ratio, indicating a strong presence of mineral dust particles (Fig. 5a), and air masses at $3000 \mathrm{~m}$ consistently originated from the Asian desert regions (Fig. 5c).

Temperatures from 19 March, 28 April 2013, 28 March 2014, and 20 March 2015 increased from approximately $290 \mathrm{~K}$ to approximately $300 \mathrm{~K}$ at middle altitudes (500 and $1200 \mathrm{~m}$ ) (Fig. 2). The temperature profile clearly indicated the presence of a thin boundary under the upper altitudes $(2500$ and $3000 \mathrm{~m}$ ), which suggested that there is a difference in air qualities between the middle and upper altitudes (Table 1). During the March 2014 time series, temperatures dynamically changed at altitudes of approximately $1200 \mathrm{~m}$, while those from the March 2015 time series $(16,17$, and 21 March 2015) were stable at $1200 \mathrm{~m}$ (Figs. S1 and S2 in the Supplement). These results indicate that the boundary layers were located at $1200 \mathrm{~m}$ 

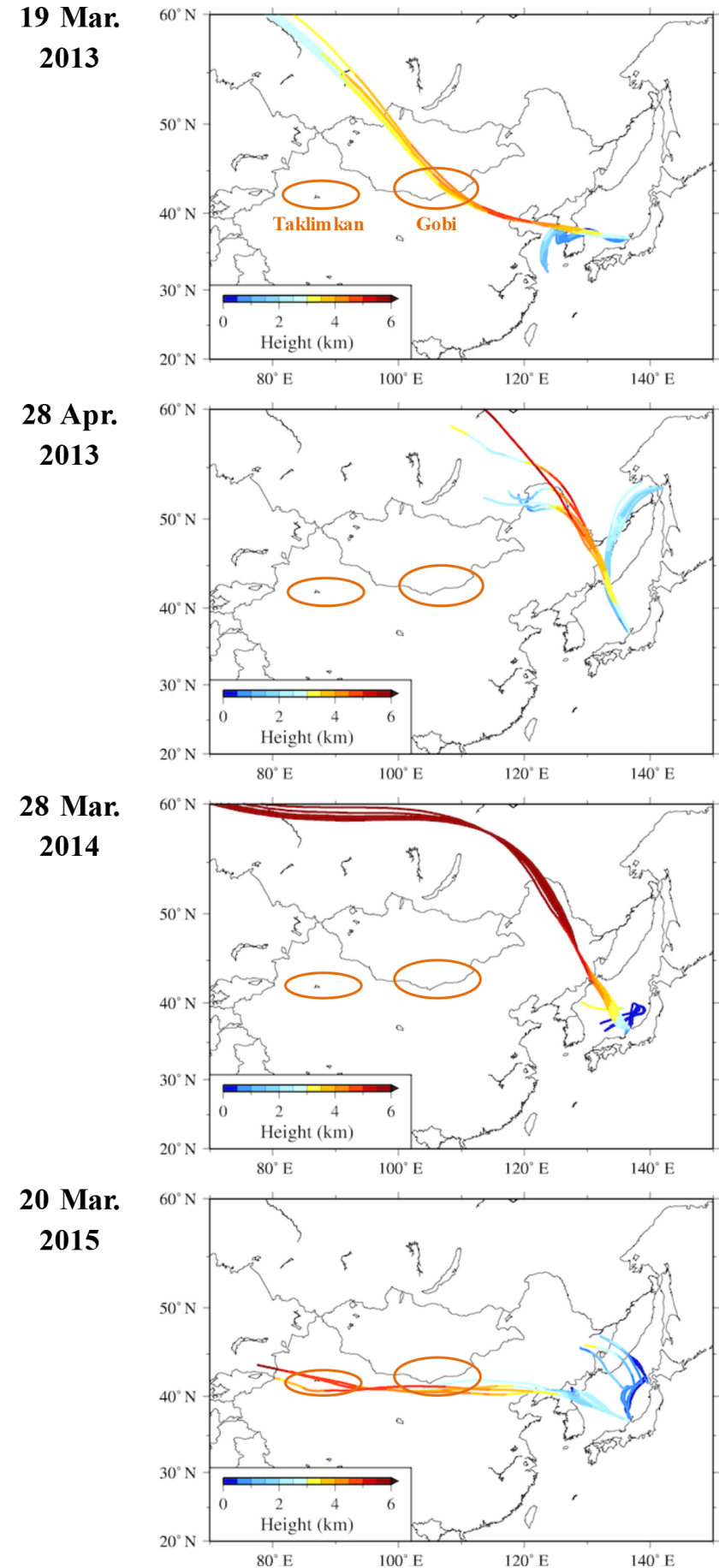

Figure 3. Three-day back trajectories of aerosols that arrived at $2500 \mathrm{~m}$ (blue-type lines) and $1200 \mathrm{~m}$ (red-type lines) in Hakui, Japan, every hour for $5 \mathrm{~h}$ before the completion of sampling time on four dates: 19 March 2013, 28 April 2013, 28 March 2014, and 20 March 2015. during the March 2014 time series, whereas the tropospheric air transported by westerly winds was suspended at the sampling altitudes (500 and $1200 \mathrm{~m}$ ) used during the March 2015 time series.

\subsection{Vertical distributions and sequential variations of aerosol particles}

Aerosol particle concentrations from the ground level to the troposphere were measured using OPC to compare the vertical distributions of aerosols from the four sampling events. The OPC-measured particles on 19 March 2013 and 20 March 2015 maintained similar concentrations below the troposphere (Fig. 2a, d), while the concentrations on 28 April 2013 and 28 March 2014 decreased 1 or 2 orders of magnitude between the troposphere and ground level (Fig. 2b, c). At high altitudes (2000 to $2500 \mathrm{~m}$ ), the course particles (greater $1.0 \mu \mathrm{m}$ ) observed on 19 March 2013 and 20 March 2015 were 1 or 2 orders of magnitude higher $\left(10^{5}\right.$ to $10^{6}$ particles $\left.\mathrm{m}^{-3}\right)$ than those on 28 April 2013 and

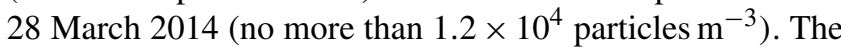
fine particles $(0.3-1.0 \mu \mathrm{m})$ showed similar concentrations between the four sampling events, fluctuating between $1.2 \times 10^{6}$ and $3.5 \times 10^{7}$ particles $\mathrm{m}^{-3}$. At lower altitudes $(130-510 \mathrm{~m})$, the aerosol particles had similar concentrations and size distributions between the four sampling periods; the course particle concentration ranged from $8.4 \times 10^{5}$ to $1.2 \times 10^{6}$ particles $\mathrm{m}^{-3}$, and the fine particles ranged from $1.3 \times 10^{7}$ to $1.2 \times 10^{8}$ particles $\mathrm{m}^{-3}$.

OPC measurements indicated that air samples collected at $1200 \mathrm{~m}$ during the March 2015 time series consistently contained course particles at 1 or 2 orders of magnitude higher in concentration $\left(1.4 \times 10^{6}\right.$ to $3.4 \times 10^{6}$ particles $\mathrm{m}^{-3}$ ) than detected in the March 2014 time series, which had concentrations of no more than $1.8 \times 10^{5}$ particles $\mathrm{m}^{-3}$ (Fig. 4b). The concentration of relatively large particles $(>5.0 \mu \mathrm{m})$ in March 2015 maintained relatively higher concentrations (from $1.4 \times 10^{4}$ to $8.2 \times 10^{5}$ particles $\mathrm{m}^{-3}$ ) than those observed in March 2014 (no more than $3.74 \times 10^{3}$ particles $\mathrm{m}^{-3}$ ). In contrast, the fine particles measured in March 2014 and March 2015 fluctuated around similar concentrations ranging from $10^{7}$ to $10^{8}$ particles $\mathrm{m}^{-3}$.

Based on the above observations, the sampled air masses that were influenced by Asian dust events and included dust particles were categorized as "dust samples". The sampled air masses that were not influenced by dust events or contained less dust particles were categorized as "non-dust samples", in relation to the presence or absence of dust events as the source of the aerosol samples (Table 1). 
(a)

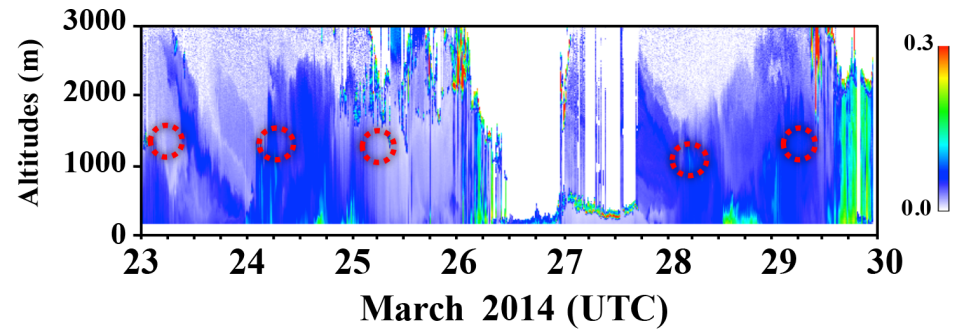

(b)

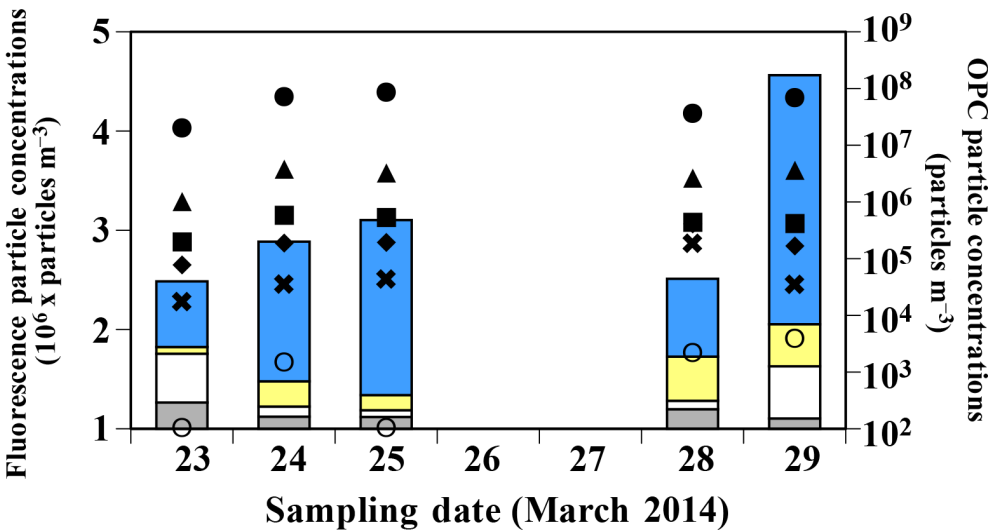

(c)

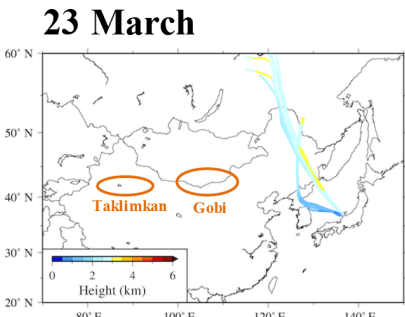

\section{March}
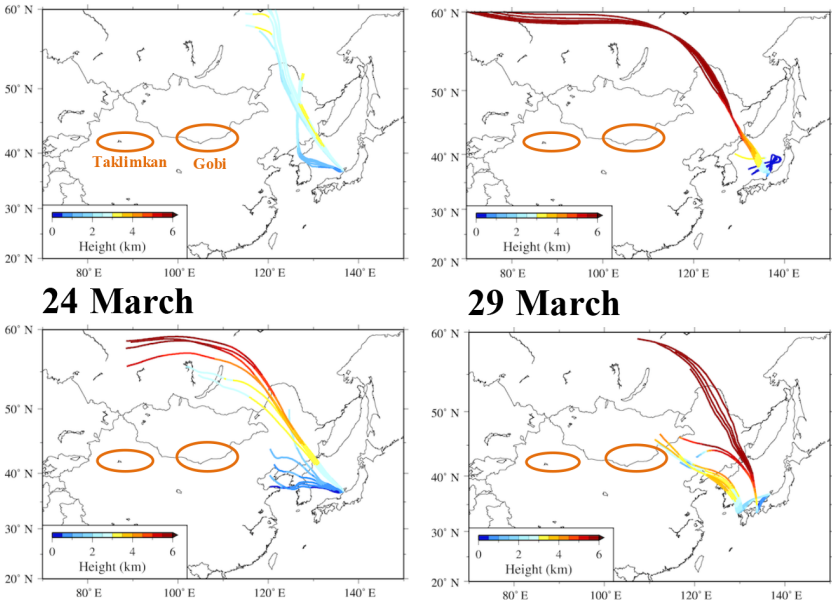

29 March

25 March
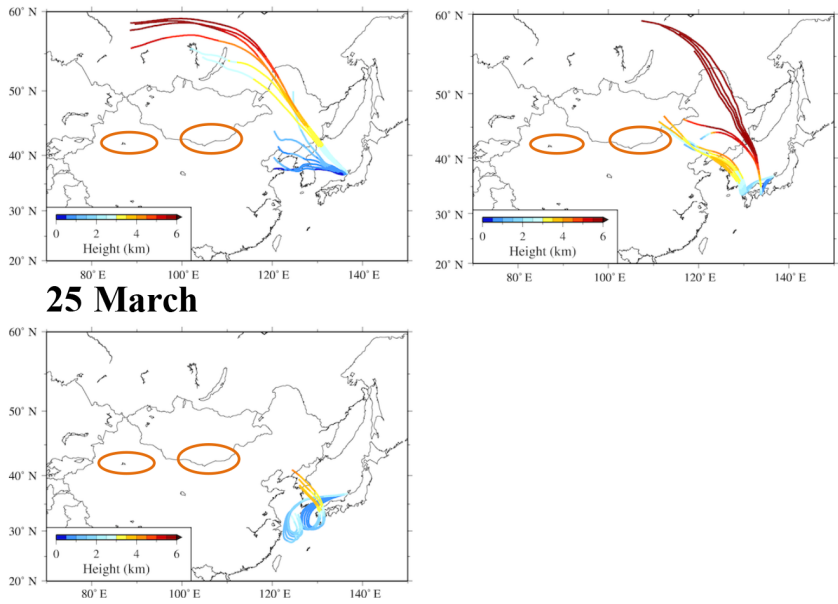

Figure 4. (a) Lidar observation of the depolarization ratio in Toyama city and concentrations of OPC-counted particles and DAPI-stained particles during non-dust days from 00:00 UTC on 23 March to 00:00 UTC on 30 March 2014. The red circles with dotted lines in the lidar images indicate dust-event influences are absent at the altitudes on the sampling time. (b) OPC-counted particles were categorized according

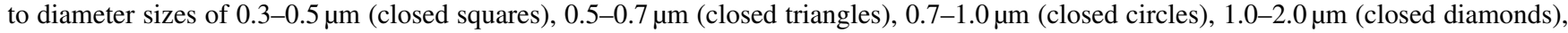
2.0-5.0 $\mu \mathrm{m}$ (crosses), and $>5.0 \mu \mathrm{m}$ (open circles). DAPI-stained particles were classified into microbial particles (blue bars), white particles (white bars), yellow particles (yellow bars), and black particles (grey bars). (c) Three-day back trajectories of aerosols that arrived at $2500 \mathrm{~m}$ (blue-type lines) and $1200 \mathrm{~m}$ (red-type lines) in Hakui, Japan, every hour for $5 \mathrm{~h}$ before the completion of sampling time during sampling periods on 23, 24, 25, 28, and 29 March 2014. 
(a)

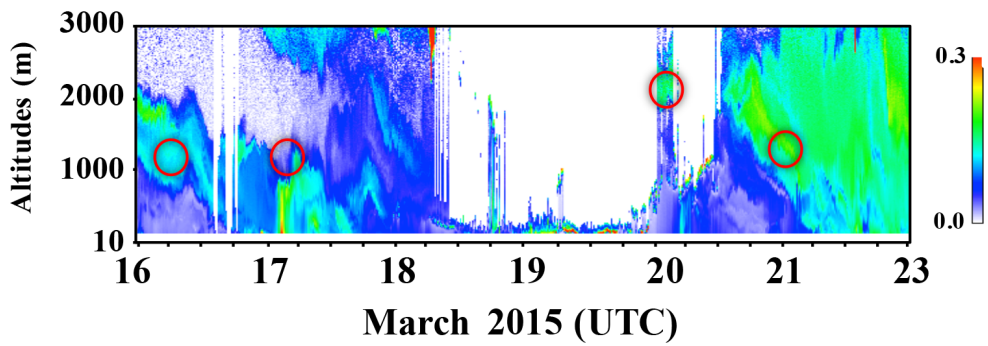

(b)

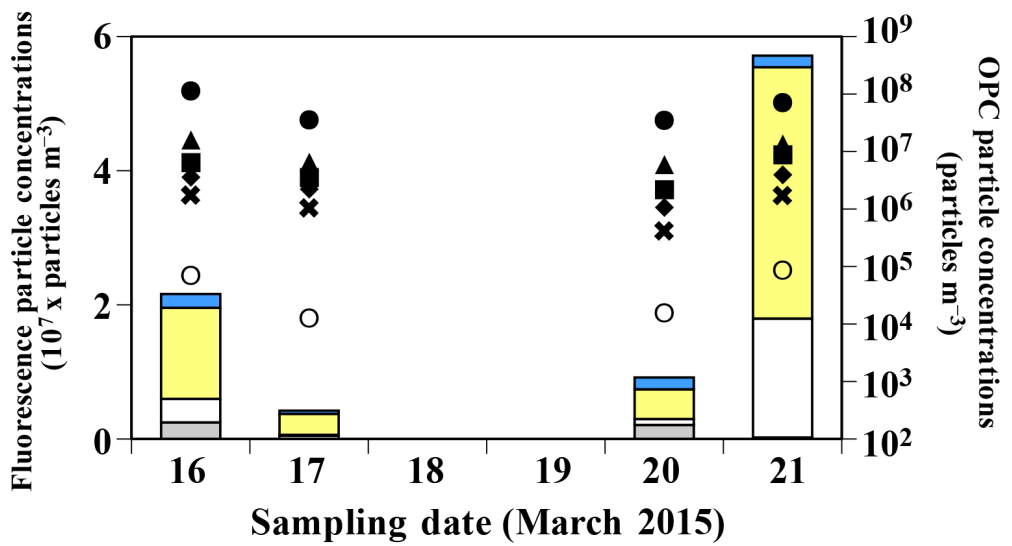

(c)

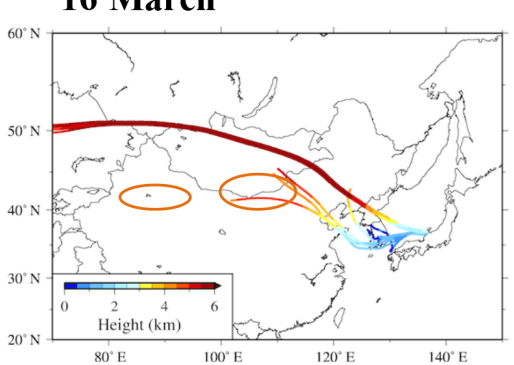

\section{March}

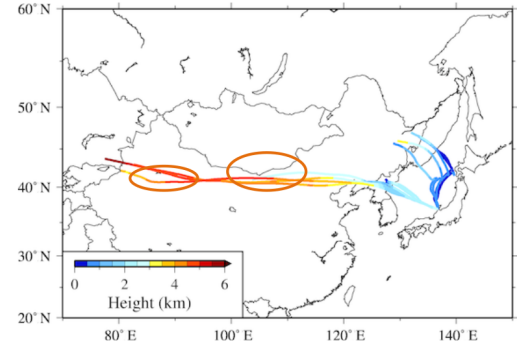

17 March
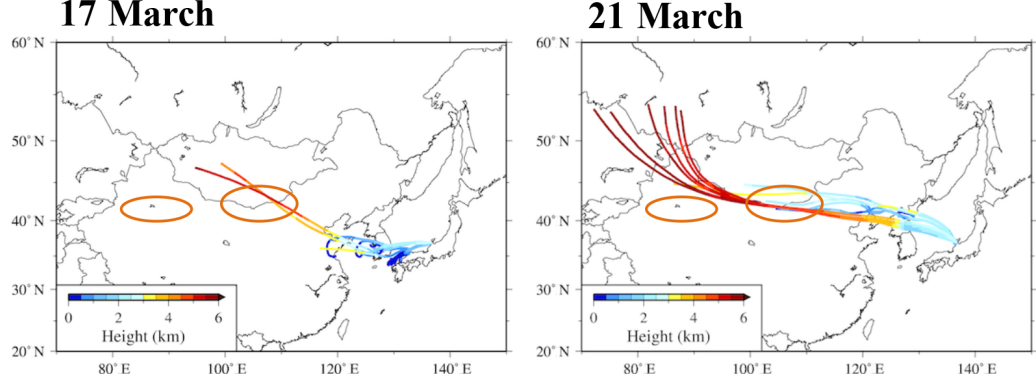

Figure 5. (a) Lidar observation of the depolarization ratio in Toyama city and concentrations of OPC-counted particles and DAPI-stained particles during dust-event days from 00:00 UTC on 16 March to 00:00 UTC on 23 March 2015. The red circles with solid lines in the lidar images indicate that the sampling air included dust mineral particles. (b) OPC-counted particles were categorized based on diameter sizes of

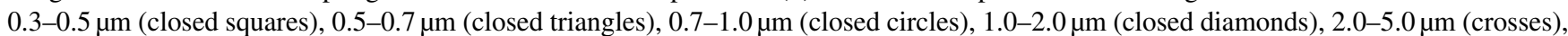
and $>5.0 \mu \mathrm{m}$ (open circles). DAPI-stained particles were classified into microbial particles (blue bars), white particles (white bars), yellow particles (yellow bars), and black particles (grey bars). (c) Three-day back trajectories of aerosols that arrived at $2500 \mathrm{~m}$ (blue-type lines) and $1200 \mathrm{~m}$ (red-type lines) in Hakui, Japan, every hour for $5 \mathrm{~h}$ before the completion of sampling time during sampling periods on 16, 17, 20, and 21 March 2015. 


\subsection{Fluorescent microscopic observation of aerosol particles}

Using epifluorescence microscopy with DAPI staining, the aerosol particles in the 18 air samples emitted several types of fluorescence, categorized as white, blue, yellow, or black (Fig. S3). White fluorescence particles, (white particles) were indicative of mineral particles originating from the sand or soil. Microbial (prokaryotic) particles stained with DAPI emitted blue fluorescence, forming coccoid- or bacilli-like particles with a diameter $<3 \mu \mathrm{m}$. Yellow fluorescence particles (yellow particles) stained with DAPI were organic matter and ranged from 1.0 to $10 \mu \mathrm{m}$ in diameter. Most of the yellow particles disappeared in the aerosol particle suspending solutions after protease treatment, suggesting that the yellow particles consisted mainly of proteins. Black particles were indicative of an anthropogenic black carbon originating from East Asian regions, produced by biomass burning, industrial activities, and vehicle exhaust.

The dust samples from upper altitudes (2500 and $3000 \mathrm{~m}$ ) contained 5 to 100 times higher concentrations of microbial, organic, and white particles than the concentrations detected in the non-dust samples (Fig. 2). In the upper-altitude dust samples, the concentration of mineral particles ranged from $7.77 \times 10^{5}$ to $1.08 \times 10^{6}$ particles $^{-3}$ (Fig. 2a, d), whereas the concentrations of the non-dust samples ranged from $3.14 \times 10^{4}$ to $1.48 \times 10^{5}$ particles $\mathrm{m}^{-3}$ (Fig. $2 \mathrm{~b}, \mathrm{c}$ ). The microbial particles in the high-altitude dust samples exhibited concentrations of approximately $1.5 \times 10^{6}$ particles $\mathrm{m}^{-3}$ that were 2 orders of magnitude higher than in the non-dust samples (approximately $6.0 \times 10^{4}$ particles $\mathrm{m}^{-3}$ ). The organic particles in the high-altitude dust samples were also found at higher concentrations of approximately $4.2 \times 10^{6}$ particles $\mathrm{m}^{-3}$ than those from the non-dust samples $13 \mathrm{H} 428$-u and $14 \mathrm{H} 328-\mathrm{u}$, which were $2.12 \times 10^{4}$ and $5.30 \times 10^{4}$ particles $\mathrm{m}^{-3}$, respectively. In contrast, the air samples collected at the low altitude of $10 \mathrm{~m}$ exhibited a random or stochastic pattern between $10^{5}$ and $10^{6}$ particles $\mathrm{m}^{-3}$, regardless of the sampling dates (Fig. 2). Black particles were observed in the four air samples from $10 \mathrm{~m}$ and fluctuated around con-

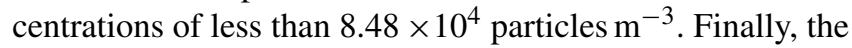
percentage of organic particles out of the total number of particles (organic and microbial particles) in the dust samples $13 \mathrm{H} 319-\mathrm{u}, 15 \mathrm{H} 320-\mathrm{u}$, and $15 \mathrm{H} 320-\mathrm{m}$ ranged between approximately 71.5 and $73.6 \%$, which was higher than in the non-dust samples, which ranged from 4.6 to $46.3 \%$ (Fig. S4).

All types of fluorescence particles were also observed in the sequentially collected air samples at $1200 \mathrm{~m}$ in the March 2015 time series (except for $2500 \mathrm{~m}$ on 20 March) and the March 2014 series. The dust samples examined from the March 2015 series had higher concentrations of total particles than the non-dust samples of the March 2014 series (Figs. 4 and 5). The mineral particles detected in the March 2014 series fluctuated at low concentrations from $3.39 \times 10^{4}$ to $2.62 \times 10^{5}$ particles $^{-3}$
(Fig. 4), while in the March 2015 series the mineral particles showed higher values from $1.80 \times 10^{5}$ to $1.77 \times 10^{7}$ particles $\mathrm{m}^{-3}$ (Fig. 5). High levels of organic particles were detected in the March 2015 series samples, ranging from $3.13 \times 10^{5}$ to $3.75 \times 10^{7}$ particles $\mathrm{m}^{-3}$, which decreased

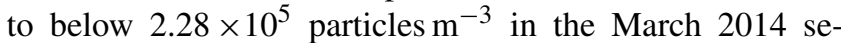
ries samples. The microbial-particle concentrations in the March 2015 series samples (ranging from $4.75 \times 10^{5}$ to $2.06 \times 10^{6}$ particles $\mathrm{m}^{-3}$ ) were higher than those of in the March 2014 series samples (ranging from $3.31 \times 10^{5}$ to $1.25 \times 10^{6}$ particles $\mathrm{m}^{-3}$ ). The ratio of organic particles to the total number of organic and microbial particles detected during March 2015 (71.5-95.6\%) were higher than those during March 2014 series (8.0-36.2\%) (Fig. S4). The black particles were randomly observed in all samples from March 2015 and March 2014.

\subsection{Analysis of bacterial communities using MiSeq sequencing analysis}

For the analysis of the prokaryotic composition in the 18 samples, we obtained 645075 merged paired-end sequences with the lengths ranging from 244 to $298 \mathrm{bp}$ after quality filtering, and the sequence library size for each sample was normalized at 1500 reads. The $16 \mathrm{~S}$ rDNA sequences were divided into 204 phylotypes (sequences with $>97 \%$ similarity). Phylogenetic assignment of sequences resulted in an overall diversity of 16 phyla and candidate divisions, 32 classes (and class-level candidate taxa), and 72 families (and family-level candidate taxa). The majority (>90\%) of the sequences were represented by 9 bacterial classes and 33 families (Figs. 6 and 7). The bacterial compositions varied during the sampling periods and included the phylotypes belonging to the classes Cyanobacteria, Actinobacteria, Bacilli, Bacteroidetes, SBRH58, and Proteobacteria (Alpha, Beta, Gamma, and Deltaproteobacteria), which are typically generated from atmospheric, terrestrial, and marine environments. On the box plots, the numbers of bacterial species estimated by Chao I were similar at average levels between the dust samples and non-dust samples, while the Chao I and Shannon values of the non-dust samples showed a wider range than that of dust samples (Fig. 8a). A NMDS plot demonstrated the distinct clustering of prokaryotic communities separating the dust samples and the non-dust samples (Fig. 8b). For the PCR-analysis steps, negative controls (no template and template from unused filters) did not contain 16S rDNA amplicons demonstrating the absence of artificial contamination during experimental processes.

\subsection{Vertical distributions of bacterial communities in dust and non-dust samples}

The vertical distributions of bacterial compositions showed different patterns between dust-event days and non-dust days (Fig. 6). In the dust samples collected at upper altitudes, 
(a)

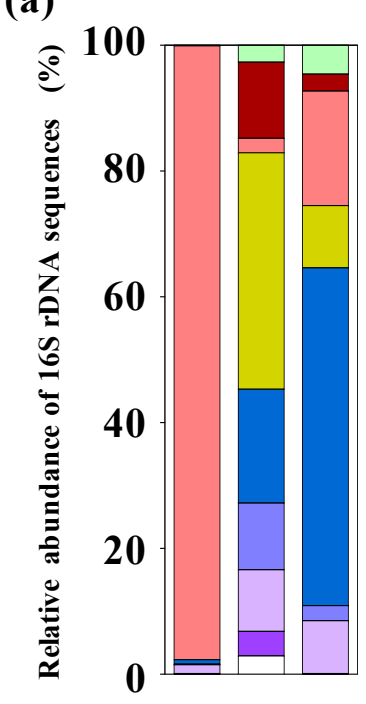

(b)

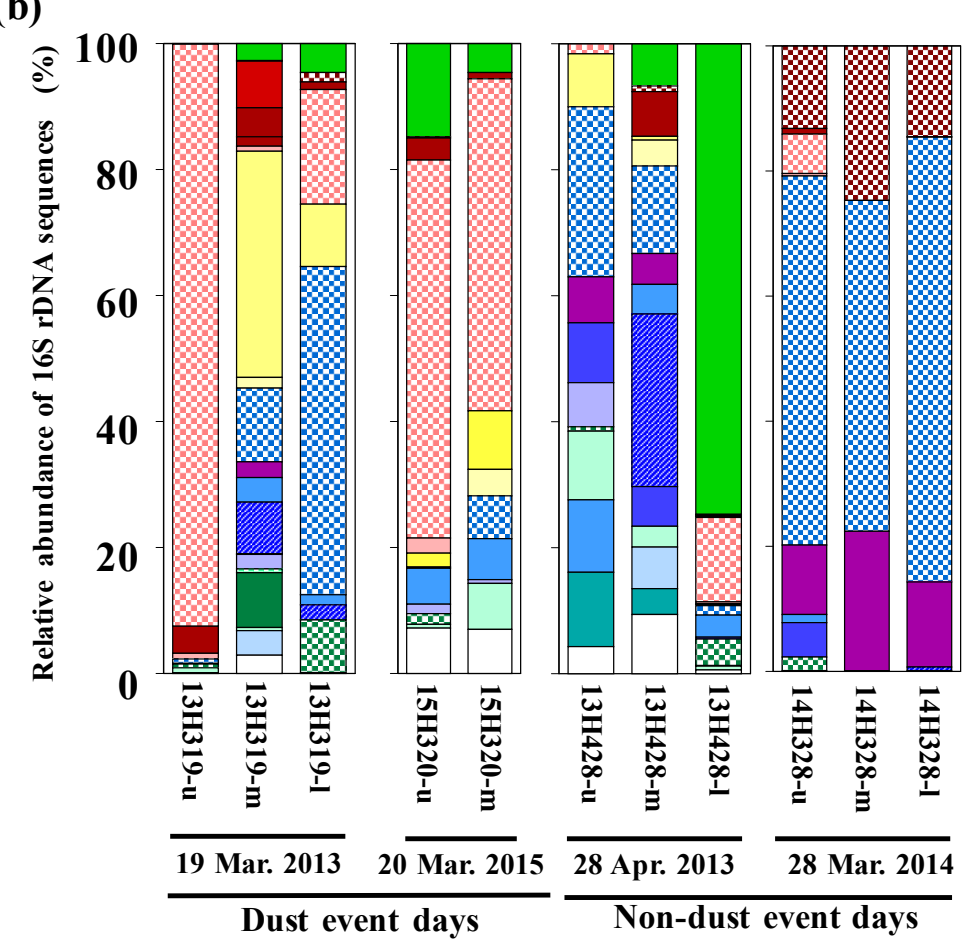

Class
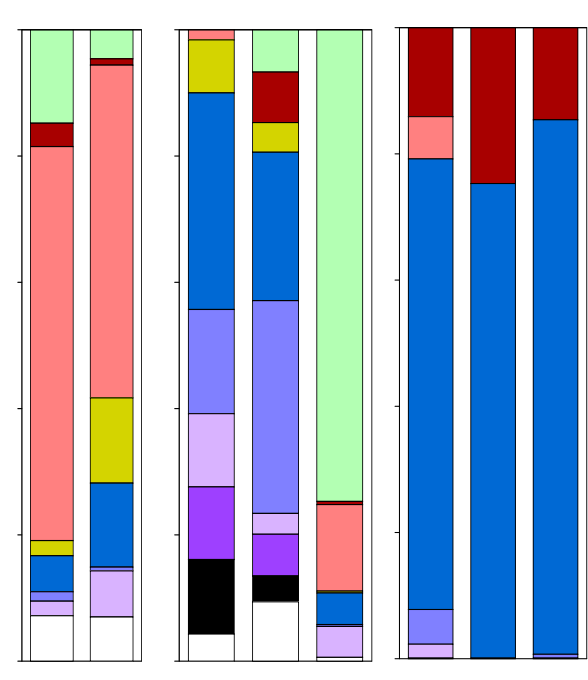

$\square$ Cyanobacteria

Actinobacteria

Bacili

Bacteroidia

Alpha

-proteobacteria

Beta

-proteobacteria

Gamma

-proteobacteria

Delta

-proteobacteria

SBRH58

Others

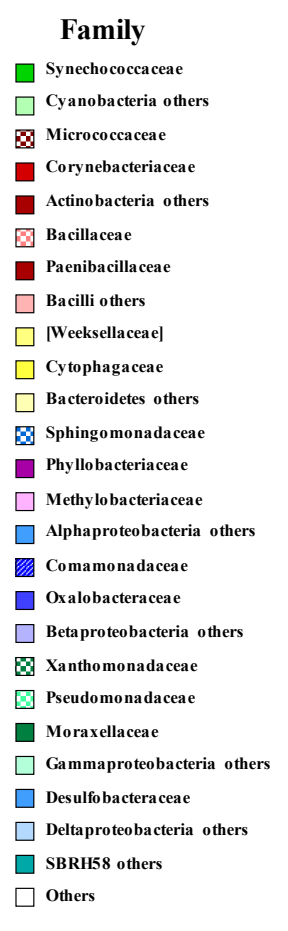

Figure 6. Vertical variations in bacterial compositions at (a) the class level and (b) the family level of the partial sequences obtained in the MiSeq sequencing database (ca. $400 \mathrm{bp}$ ) obtained from air samples collected at different altitudes over the Noto Peninsula at dust-event days (19 March 2013; 20 March 2015) and non-dust-event days (19 March 2013; 20 March 2015).

phylotypes belonging to the phylum Bacilli accounted for more than $60.5 \%$ of the total and were mainly composed of members of the families Bacillaceae and Paenibacilliaceae (Fig. 6). Bacterial numbers from the phylum Bacilli decreased at lower altitudes during dust events, and the phylotypes of Cyanobacteria, Actinobacteria, and Proteobacteria increased in relative abundance in the samples col- lected at middle and low altitudes (13H319-m, 13H319-1, and 15H320-m).

Cyanobacteria, Actinobacteria, and Proteobacteria sequences also dominated in the air samples collected during non-dust events (13H428-m, 14H328-u, 14H328-m, and 14H328-1). Specifically, Actinobacteria phylotypes increased in their relative abundance, ranging from 14.1 to $24.7 \%$ in the non-dust samples collected on 28 March 2014. Pro- 
(a)

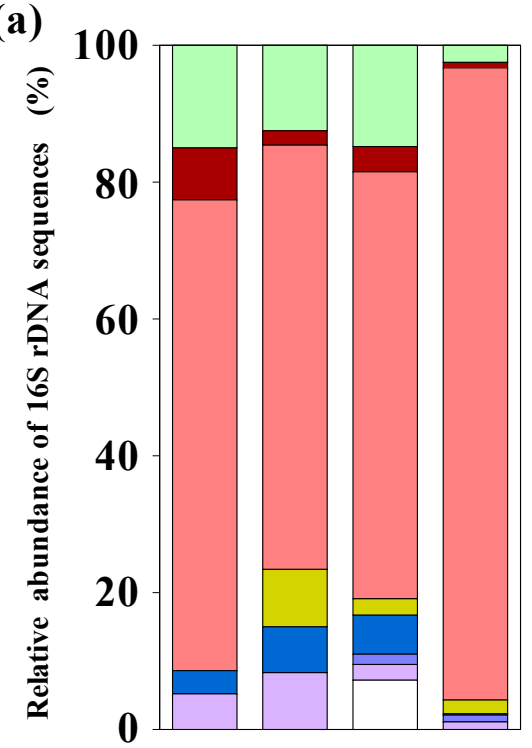

(b)

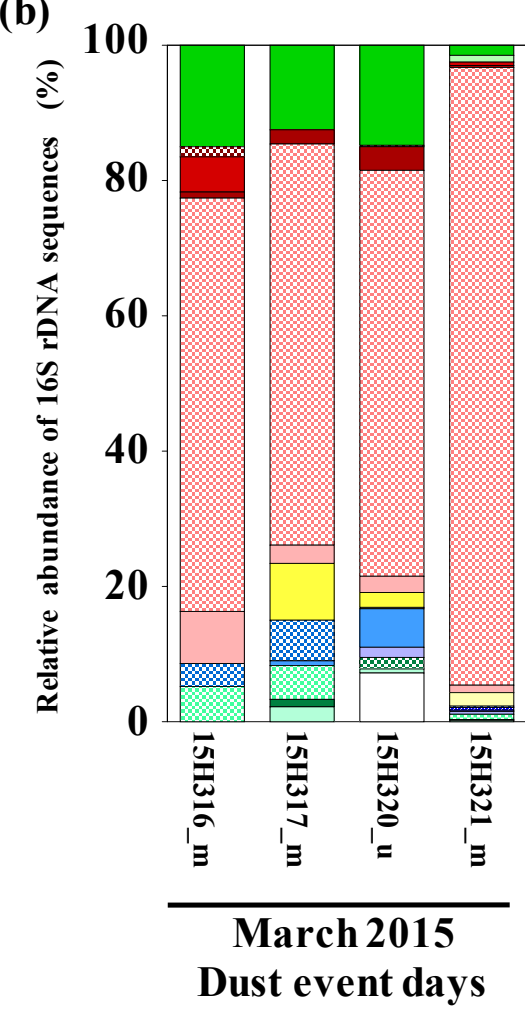

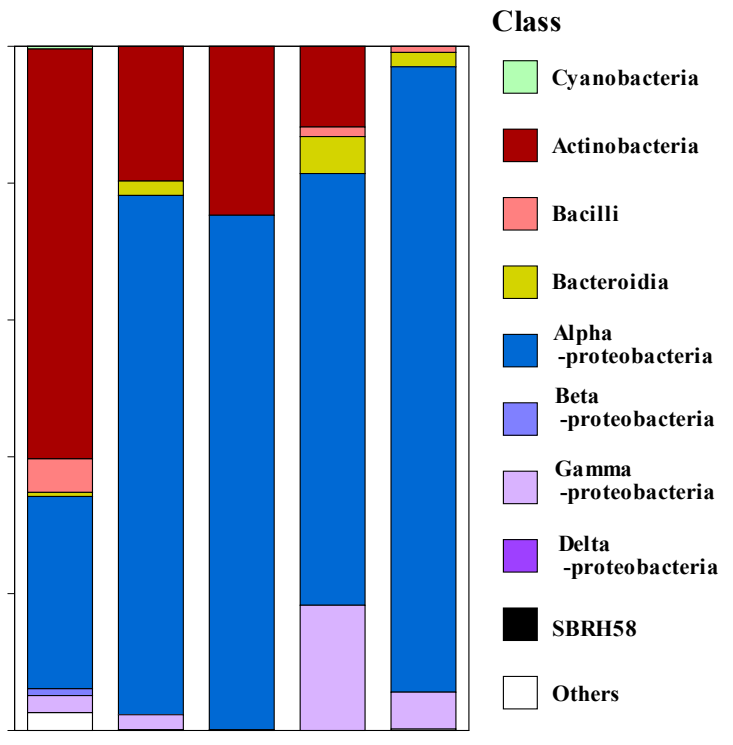

Family

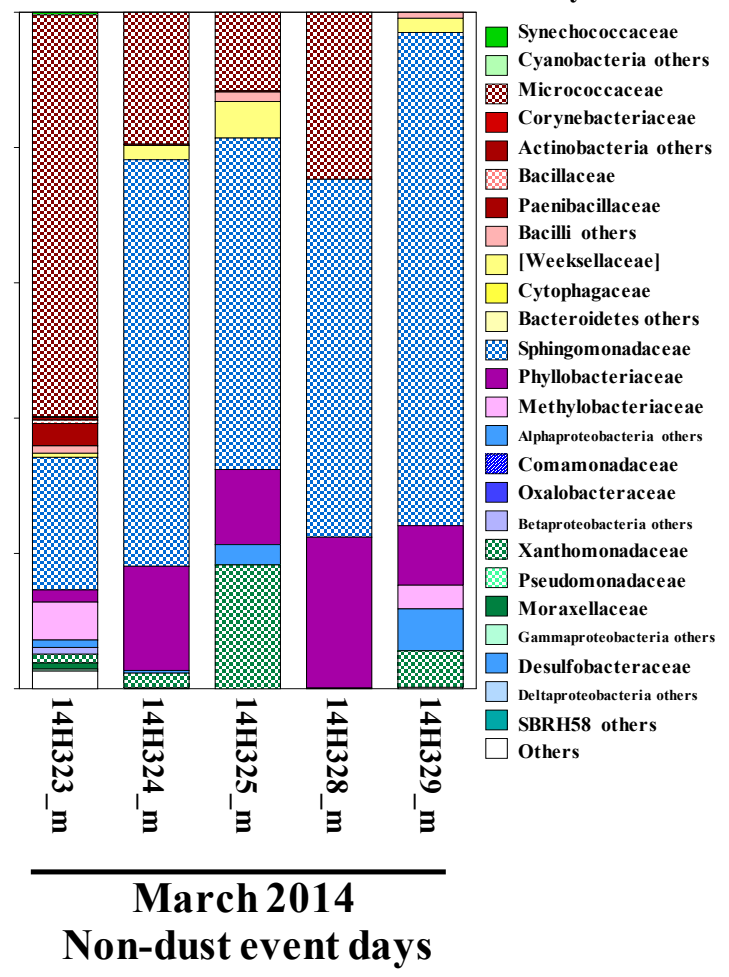

Figure 7. Changes in bacterial compositions at (a) the class level and (b) the family level of the partial sequences obtained in the MiSeq sequencing database (ca. $400 \mathrm{bp}$ ) from air samples collected at altitudes of $1200 \mathrm{~m}$ (except for the sample collected at $500 \mathrm{~m}$ on $20 \mathrm{March} 2015$ ) over the Noto Peninsula during dust-event days from 16 to 23 March 2015 and during non-dust-event days from 23 to 29 March 2014.

teobacteria phylotypes containing several bacterial families occupied a high relative abundance, ranging from 60.5 to $85.3 \%$ in the non-dust samples $13 \mathrm{H} 428-\mathrm{u}, 13 \mathrm{H} 428-\mathrm{m}$, 14H328-u, 14H328-m, and 14H328-1. In particular, the nondust samples collected on 28 March 2014 included the Alphaproteobacteria phylotypes, which are composed of mem- bers of the families Phyllobacteriaceae and Sphingomonadaceae. Most Betaproteobacteria, phylotypes including the families Oxalobacteraceae and Comamonadaceae, were specific to the non-dust samples collected at 1200 and $2500 \mathrm{~m}$ on 28 April 2013. 
(a)

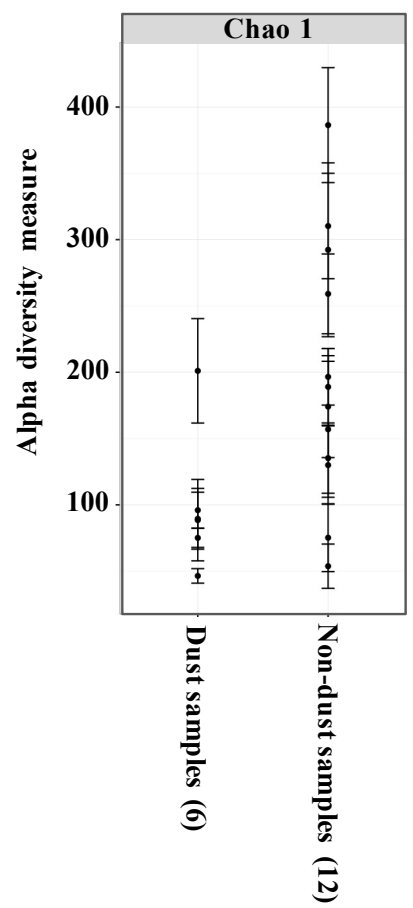

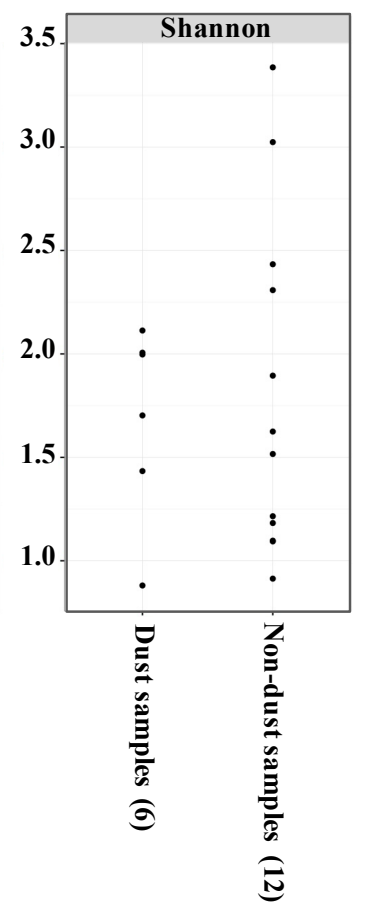

(b)

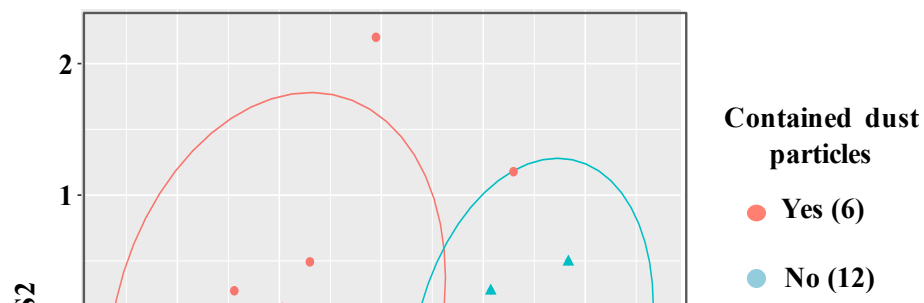

Dust event day

Yes (8)

No (10)

Figure 8. Comparison of the bacterial compositions among all air samples collected over the Noto Peninsula. (a) Box plots of Chao 1 and Shannon analyses indicating the bacterial diversity observed in dust samples and non-dust samples. Species were binned at the $97 \%$ sequence similarity level. (b) NMDS of the pairwise Bray-Curtis distance matrix displaying clustering by all the air samples. Red indicates the samples that were collected during dust events and blue indicates those collected during non-dust events as determined by meteorological data. Circles indicate that the sample contained dust particles as identified via microscopic observation, and triangles indicate that dust particles were absent from the sample. The confidence ellipses are based on a multivariate $t$ distribution and represent the $95 \%$ confidence interval of the occurrence of dust vs. non-dust events when the samples were collected.

Cyanobacteria phylotypes, which were randomly detected from both dust samples and non-dust samples, particularly increased in both the non-dust sample collected at $10 \mathrm{~m}$ on 28 April 2013 and the dust sample collected at $3000 \mathrm{~m}$ on 20 March 2015, with a relative abundance of 15.3 and $74.6 \%$, respectively. Bacteroidia phylotypes also randomly appeared in several air samples, regardless of the dust-event influences, and were present at maximal levels in the nondust sample $13 \mathrm{H} 319-\mathrm{m}$, with a relative abundance of $35.6 \%$.

\subsection{Variations in bacterial communities during dust events and non-dust events}

Sequential variations in the bacterial composition of air samples at altitudes of 1200 or $2500 \mathrm{~m}$ were compared between dust-event periods (March 2015 series) and non-dust periods (March 2014 series). During the March 2015 dust event, phylotypes of the family Bacillaceae in the class Bacilli occupied more than $53.0 \%$ of the relative abundance in the four dust samples collected (Fig. 7). Cyanobacteria phylotypes related to the marine cyanobacterium Synechococcus uniquely appeared in the dust samples of the March 2015 series; their abundance fluctuated, with values ranging from 12.5 to $14.8 \%$ between 16 and 20 March 2015 before decreasing to $1.5 \%$ on 20 March.

During the non-dust periods of the March 2014 series at the middle altitude, the relative abundance of Actinobacteria phylotypes belonging to the family Micrococcaceae was occupied $59.9 \%$ on 23 March, decreased to $19.5 \%$ on 24 March, and disappeared from samples collected on 29 March. Corresponding to the decrease in Actinobacteria phylotypes, Alpha- and Gammaproteobacteria phylotypes showed an increasing trend from 30.6 to $96.8 \%$ between 23 and 29 March 2014 (Fig. 7a). Alphaproteobacteria phylotypes belonging to the families Sphingomonadaceae, and Phyllobacteriaceae consistently appeared throughout the sampling periods of the March 2014 series and occupied a maximum relative abundance of 72.9 and $22.3 \%$, respectively. For Gammaproteobacteria, the Xanthomonadaceae sequences dominated at a relative abundance of 18.3 and $5.4 \%$ in the non-dust samples $14 \mathrm{H} 325-\mathrm{m}$ and $14 \mathrm{H} 329-\mathrm{m}$, respectively, during the air mass was suspended the Japanese islands for a few days. 


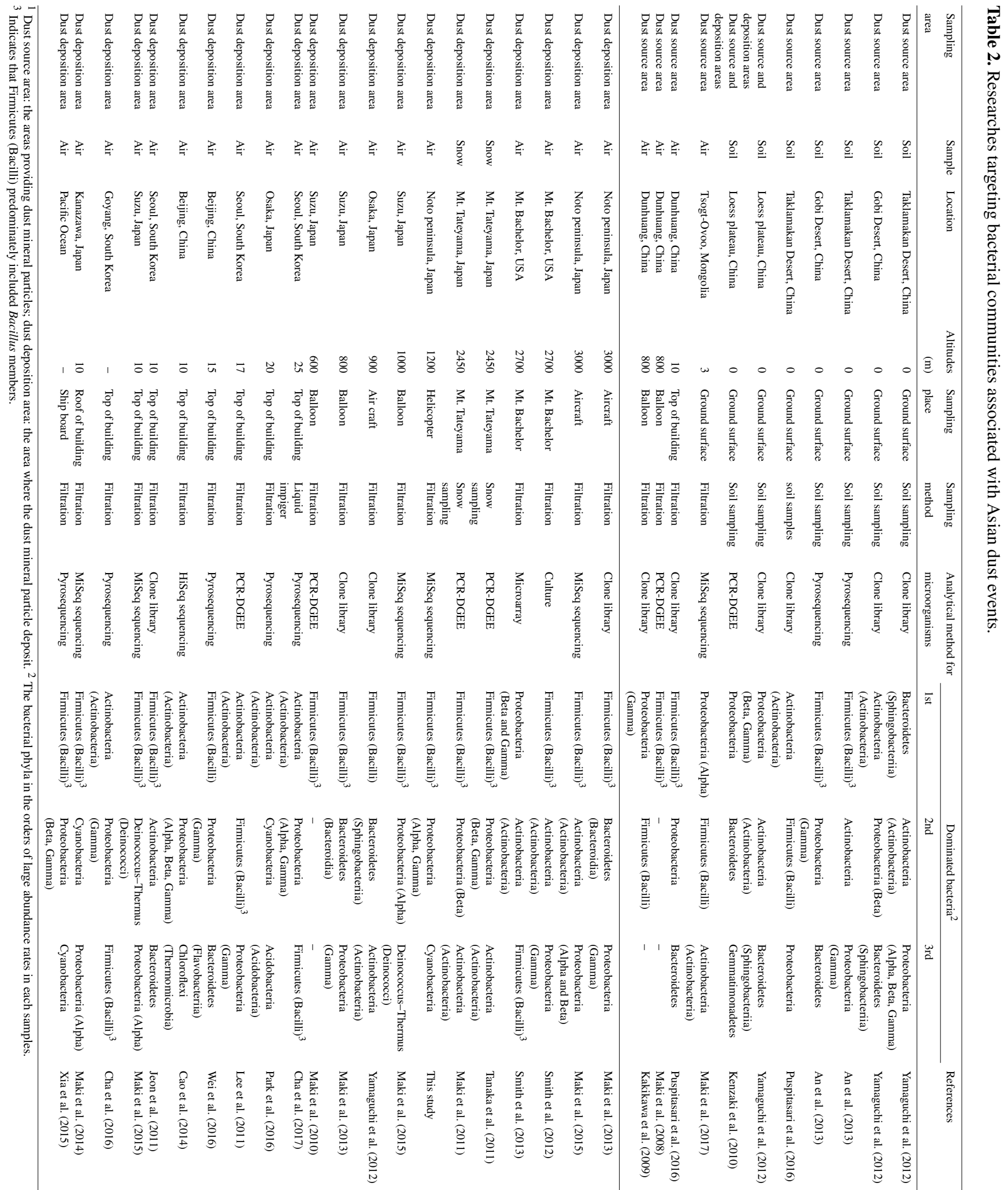




\section{Discussion}

\subsection{Air mass conditions during Asian dust and non-dust events}

Westerly winds blowing over East Asia disperse airborne microorganisms associated with dust mineral particles (Maki et al., 2008) and anthropogenic particles (Cao et al., 2014; Wei et al., 2016), influencing the abundances and taxon compositions of airborne bacteria at high altitudes over downwind areas, such as Noto Peninsula (Maki et al., 2013). In this investigation, the increases in aerosol particles (dust particles) and associated microbial particles were observed over the Noto Peninsula during the dust events of 19 March 2013 and 20 March 2015 (Figs. 2 and 4). At the two sampling dates, the air mass including microbial particles had travelled from the Asian desert region throughout the anthropogenic polluted areas (Fig. 2), and the dust particles entered the Japanese troposphere and were maintained at high altitudes (19 March 2013) or mixed with the ground-surface air (20 March 2015). During non-dust days, the air masses at high altitudes came from several areas, including the eastern region of Siberia, Asian continental coasts (Korean Peninsula), the Sea of Japan, or surrounding Japanese islands, and mixed with ground-surface air over the Noto Peninsula. The air samples collected during dust and non-dust events were valuable for understanding the westerly wind influences on vertical distributions and sequential dynamics of airborne bacteria at high altitudes over the downwind regions.

\subsection{Aerosol dynamics during Asian dust and non-dust event}

The microscopic fluorescence particles of all samples could be separated into four categories: mineral (white), microbial (blue), organic (yellow), and black carbon (black) particles (Fig. S3), which were observed in the previous air samples collected during dust events (Maki et al., 2015). The amount of microbial particles increased at high altitudes during dust events, suggesting that the dust events directly carried bacterial particles to the troposphere over downwind areas. At low altitudes, similar concentrations of fluorescent particles were observed in air samples collected between dust events (13H319-1) and non-dust events (13H428-1) (Fig. 2) because the dust particles did not reach the ground surface on the dust-event days. In the absence of the influences of dust events, the aerosols mainly originated from local environments in Japanese areas.

Organic particles also increased during dust events and in the ratios between all particles related to the dust events. The organic particles originate from proteins and other biological components (Mostajir et al., 1995). The tropospheric aerosols would be composed of organic particles at high rates ranging from 30 to $80 \%$ (Jaenicke, 2005), and organic particle concentrations fluctuated from $10^{3}$ to $10^{5}$ particles $\mathrm{m}^{-3}$ at high altitudes of $4000 \mathrm{~m}$ above the ground (Twohy et al., 2016). The dead-phase cells of microbial isolates obtained from aerosol samples mainly irradiated yellow fluorescence instead of blue fluorescence (Liu et al., 2014). When fungi (Bjerkandera adusta) and bacteria (Bacillus spp.) isolated from aerosol samples were incubated, the dead-phase microbial cells mainly irradiated yellow fluorescence instead of blue fluorescence (Liu et al., 2014; Fig. S3). The relative numbers of organic particles to the total number of microbial and organic particles in the dust samples showed significantly higher values $(82.9 \pm 32.3 \%)$ than in the non-dust samples (23.3 $\pm 13.7 \%)$ (Fig. S4). Hara and Zhang reported that dust events in Kyushu, Japan, resulted in an increased ratio of damaged microbial cells in the air at the groundsurface and that the ratio increased to approximately $80 \%$ (Hara and Zhang, 2012). Furthermore, organic molecules associated with dust aerosols are reported to be composed of mannitol, glucose, and fructose, which are part of cell components of airborne microorganisms and contribute to the formation of secondary organic aerosols (SOA) (Fu et al., 2016). Microbial cells or their components coming from Asian continents to Japan would be exposed to air at high altitudes during their long-range transport, increasing the ratios of damaged and dead cells or SOA.

The appearance of black carbon most likely originated from anthropogenic activities, such as biomass burning, industrial activities, and vehicle exhaust (Chung and Kim, 2008). In the anthropogenic regions of eastern China, anthropogenic particles originating from human activities are expected to comprise more than $90 \%$ of dust particles (Huang et al., 2015a). When the westerly winds are strongly blowing over the Noto Peninsula, the black carbon particles at upper altitudes $(3000 \mathrm{~m})$ are thought to mainly derive from continental anthropogenic regions.

\subsection{Comparing the community structures of atmospheric bacteria between Asian dust and non-dust events}

Dust events and air pollutant occurrences changed the airborne bacterial communities over the downwind areas, such as Beijing (Jeon et al., 2011; Cao et al., 2014) (Table 2) and eastern Mediterranean areas (Mazar et al., 2016). The westerly winds blowing over East Asia would transport airborne bacteria to the high-altitude atmosphere over the Noto Peninsula (Maki et al., 2015) and North American mountains (Smith et al., 2013). Our box plots analysis suggested that changes in the bacterial diversity in the dust samples would be more stable than in the non-dust samples (Fig. 8a). Furthermore, using a NMDS plot, the bacterial compositions in the dust samples could be distinguished from non-dust samples (Fig. 8b). Thus, the aerosol particles transported by Asian dust events changed the atmospheric bacterial composition at higher altitudes over downwind areas. 
The phylotypes in the dust samples were predominately clustered into the class Bacilli (Fig. 4a), while the nondust samples mainly included the phylotypes of the classes Alpha, Beta, and Gammaproteobacteria and Actinobacteria. Our previous investigations indicated that the bacterial communities at an altitude of $3000 \mathrm{~m}$ over the Noto Peninsula included more than 300 phylotypes, which were predominantly composed of Bacilli phylotypes (Maki et al., 2015). Bacterial groups belonging to Bacilli, Proteobacteria, and Actinobacteria have been reported as airborne bacteria around European mountains (Vaïtilingom et al., 2012) and over Asian rural regions (Woo et al., 2013). Some Bacilli isolates were found to act as ice-nucleating agents and to be involved in ice cloud (Matulova et al., 2014; Mortazavi et al., 2015). Isolates of Gammaproteobacteria isolates were obtained from mineral dust particles (Hara et al., 2016a), glaciated high-altitude clouds (Sheridan et al., 2003), and plant bodies (Morris et al., 2008), and some isolate species, such as Pseudomonas, were confirmed to have the ice-nucleation activity. Accordingly, Bacilli and Proteobacteria members associated with dust events could potentially contribute to climate change resulting from dust events.

\subsection{Dominant bacterial populations in the air masses transported from Asian continents}

In some dust-event samples collected at high altitudes (13H319-u, 15H320-u, and 15H320-m), Bacilli sequences accounted for more than $52.7 \%$ of the total number of sequences (Fig. 6). Back trajectories on 19 March 2013 and 20 March 2015 came from the Asian desert region to the Noto Peninsula. Some Bacillus species were predominantly detected at high altitudes above the Taklamakan Desert (Maki et al., 2008) and above downwind areas during Asian dust events (Maki et al., 2010, 2013; Smith et al., 2013; Jeon et al., 2011; Tanaka et al., 2011) (Table 2). Bacillus species are the most prevalent isolates obtained from mineral dust particles collected over downwind areas (Hua et al., 2007; Gorbushina et al., 2007).

Bacilli members can form resistant endospores that support their survival in the atmosphere (Nicholson et al., 2000). The Bacillus isolates obtained from atmospheric samples showed higher-level resistance to UV irradiation than normal isolates (Kobayashi et al., 2015). In the Gobi Desert, dust events increase the diversity of airborne microbial communities; after dust events, spore-forming bacteria, such as Bacillus, increase in their relative abundances (Maki et al., 2016). Accordingly, in the atmosphere, selected Bacilli members associated with dust particles would be transported over long distances.

The Bacilli sequences showed different vertical variations between the two dust events on 19 March 2013 and 20 March 2015. On 19 March 2013 (13H319-m), the relative abundances of Bacilli sequences decreased dynamically from 3000 to $1200 \mathrm{~m}$, while unstable atmospheric layers on
20 March 2015 most likely mixed the long-range transported bacteria with the regional bacteria over the Noto Peninsula. A previous investigation also demonstrated the vertical mixture of airborne bacteria over Suzu in the Noto Peninsula (Maki et al., 2010).

Actinobacteria sequences decreased in relative abundance between 23 and 29 March 2014, corresponding with changes in the air mass trajectory roots from north Asian regions, such as eastern Siberia and Japan (Fig. 7). Furthermore, Actinobacteria sequences appeared in the samples collected from air masses that were transported throughout the Korean Peninsula on 19 March 2013, 28 April 2013, and 20 March 2015. Actinobacteria members are frequently dominant in terrestrial environments but seldom survive in the atmosphere for a long time, because they cannot form spores (Puspitasari et al., 2015). However, the family Micrococcaceae in Actinobacteria was primarily detected from anthropogenic particles collected in Beijing, China (Cao et al., 2014). Over anthropogenic source regions for Asian continents, anthropogenic particles occupy more than $90 \%$ of dust particles and originate from soils disturbed by human activities in cropland, pastureland, and urbanized regions (Huang et al., 2015a; Guan et al., 2016). Air masses transported from the continental coasts are expected to include a relatively high abundance of Actinobacteria members associated with anthropogenic particles.

Natural dust particles from Asian desert areas (Taklamakan and Gobi) are transported in the free troposphere (Iwasaka et al., 1988) and vertically mixed with anthropogenic particles during the transportation processes (Huang et al., 2015a). In some cases, short-range transport of air masses would carry only anthropogenic particles to Japan, because the anthropogenic particles are often dominant in Asian continental coasts (Huang et al., 2015a). Actinobacteria members may have been transported with anthropogenic particles from continental coasts.

\subsection{Dominant bacterial populations in the air masses originated from marine environments and Japanese islands}

Proteobacteria sequences increased in their relative abundances at high altitudes during non-dust sampling dates (13H428-u, 13H428-m, 14H328-u, 14H328-m, and March 2014 series), when air mass origins at $1200 \mathrm{~m}$ changed from the Korean Peninsula to Japan (Fig. 7). Proteobacteria members were the dominate species in the atmosphere over mountains (Bowers et al., 2012; Vaïtilingom et al., 2012; Temkiv et al., 2012), in the air samples collected on a tower (Fahlgren et al., 2010), and from the troposphere (DeLeon-Rodriguez et al., 2013; Kourtev et al., 2011). In the phylum proteobacteria, the families Phyllobacteriaceae, Methylobacteriaceae, and Xanthomonadaceae were predominately detected from the non-dust samples and are associated with plant bodies or surfaces (Mantelin et al., 2006; Fürnkranz et al., 2008; 
Khan and Doty, 2009; Fierer and Lennon, 2011). The Betaproteobacteria sequences in the non-dust samples mainly contained the Oxalobacteraceae and Comamonadaceae families, which are commonly dominate in freshwater environments (Nold and Zwart, 1998) and on plant leaves (Redford et al., 2010). In addition, the class Alphaproteobacteria in the non-dust samples also included marine bacterial sequences belonging to the family Sphingomonadaceae (Cavicchioli et al., 2003). Bacterial populations originating from marine areas are prevalent in cloud droplets (Amato et al., 2007), in air samples collected from the seashores of Europe (Polymenakou et al., 2008), in storming troposphere (DeLeonRodriguez et al., 2013), and at high altitudes in Japanese regions (Maki et al., 2014), suggesting that the marine environments represent a major source of bacteria in clouds. The air masses suspended over the Sea of Japan or Japanese islands during non-dust events (the March 2014 series) could include a high relative abundance of airborne bacteria, which were transported from the surface-level air over the marine environments and the regional phyllosphere.

\subsection{Bacterial populations commonly detected during dust events and the non-dust events}

Sequences originating from Synechococcaceae (in the class Cyanobacteria) randomly appeared in the MiSeq sequencing databases results obtained from air samples, regardless of dust-event occurrences. Synechococcus species in the family Synechococcaceae can eliminate excess peroxide from photosynthesis to resist UV radiation and oxygenic stress (Latifi et al., 2009), suggesting that these bacteria resist environmental stressors in the atmosphere. In a previous study, the air samples transported from marine environments to Japan predominately contained Synechococcus species (Maki et al., 2014), which were dominant marine bacteria in the Sea of Japan and the East China Sea (Choi and Noh, 2009). The cloud water at approximately $3000 \mathrm{~m}$ a.g.l. was also dominated by Cyanobacteria populations, indicating their atmospheric transport (Kourtev et al., 2011). In addition to Alphaproteobacteria, marine cyanobacterial cells can be transported from seawater to the atmosphere, thereby contributing to the airborne bacterial variations over the Noto Peninsula. Marine bioaerosols originated from cyanobacteria and gram-negative bacteria (including Alphaproteobacteria) are reported to contribute the increase of endotoxin levels in coastal areas influencing human health by inflammation and allergic reaction (Lang-Yona et al., 2014).

Bacteroidetes sequences were detected in some air samples collected during Asian dust and non-dust events. Members of the phylum Bacteroidetes, which were composed of the families Cytophagaceae, associate with organic particles in terrestrial and aquatic environments (Turnbaugh et al., 2011; Newton et al., 2011). Furthermore, these bacterial populations dominate the atmosphere and sand of desert areas, where plant bodies and animal feces are sparsely present
(Maki et al., 2016). These bacterial groups possibly originated from organic-rich microenvironments in several areas, such as desert and marine areas.

\section{Conclusion}

Air samples including airborne bacteria were sequentially collected at high altitudes over the Noto Peninsula during dust events and non-dust events. The sampled air masses could be categorized based on sample types with (dust samples) and without (non-dust samples) dust-event influences. Bacterial communities in the air samples displayed different compositions between dust events and non-dust events. The dust samples were dominated by terrestrial bacteria, such as Bacilli, which are thought to originate from the central desert regions of Asia, and the bacterial compositions were similar between the dust samples (Table 2). In contrast, the air masses of non-dust samples came from several areas, including northern Asia, continental coasts, marine areas, and Japan regional areas, showing different variations in bacterial compositions between the sampling dates. Some scientists have attempted to apply airborne bacterial composition as tracers of air mass sources at ground level (Bowers et al., 2011; Mazar et al., 2016). In this study, the terrestrial bacteria, such as Bacilli and Actinobacteria members (Bottos et al., 2014), were dominant populations in the air samples transported from Asian continental areas. The air samples when the air mass was suspended around Japanese islands, mainly included the members of the classes Alpha- (Phyllobacteriaceae and Methylobacteriaceae), Gamma-, and Betaproteobacteria, which are commonly dominated in phyllosphere (Redford et al., 2010; Fierer and Lennon, 2011) or freshwater environments (Nold and Zwart, 1998). The atmospheric aerosols transported via marine areas include a high relative abundances of marine bacteria belonging to classes Cyanobacteria (Choi and Noh, 2009) and Alphaproteobacteria (Sphingomonadaceae) (Cavicchioli et al., 2003). This study suggested that bacterial compositions in the atmosphere can be used as air mass tracers, which could identify the levels of mixed air masses transported from different sources.

However, one limitation of our investigation is that the number of samples analysed was not sufficient to cover entire changes in airborne bacteria at high altitudes over the Noto Peninsula. Although the airborne bacterial composition during non-dust periods was found to change dynamically, only a few types of variation were followed in this investigation. In the future, greater numbers of samples, which are sequentially collected at high altitudes using this sampling method, will need to be originated to more accurately evaluate bioaerosol tracers. Since helicopter sampling procedures require sophisticated techniques and are expensive, the sample numbers at high altitudes are difficult to increase. Air sampling at high altitudes should be combined with se- 
quential ground-air sampling to advance the understanding of the influence of westerly winds on airborne bacterial dynamics in downwind areas. Metagenomic analyses and microbial culture experiments would also provide valuable information about airborne microbial functions relating to icenucleation activities, chemical metabolism, and pathogenic abilities.

Data availability. The lidar measurement data are accessible from http://www-lidar.nies.go.jp. The back-trajectory data were calculated from the NOAA HYSPLIT model (http://www.arl.noaa. gov/HYSPLIT.php). All data obtained from MiSeq sequencing data have been deposited in the DDBJ/EMBL/GenBank database (http://www.ddbj.nig.ac.jp/index-e.html: accession number is PRJEB17915). The other data are available from the authors upon request.

\section{The Supplement related to this article is available online at https://doi.org/10.5194/acp-17-11877-2017- supplement.}

Competing interests. The authors declare that they have no conflict of interest.

Special issue statement. This article is part of the special issue "Anthropogenic dust and its climate impact". It is not associated with a conference.

Acknowledgements. We are thankful for the advice given by Richard C. Flagan of California Institute of Technology and the sampling support from Atsushi Matsukia and Makiko Kakikawa of Kanazawa University. Trajectories were produced by the NOAA Air Resources Laboratory (ARL), which provided the HYSPLIT transport and dispersion model and/or READY website (http://www.ready.noaa.gov). Members of Fasmac Co., Ltd. helped with the MiSeq sequencing analyses. This research was funded by the grant-in-aid for scientific research (B) (no. 26304003) and (C) (no. 26340049). The Bilateral Joint Research Projects from the Japan Society for the Promotion of Science also supported this work, as did the Strategic International Collaborative Research Program (SICORP: 7201006051) and Strategic Young Researcher Overseas Visits Program for Accelerating Brain Circulation (no. G2702). This study was supported by the Joint Research Program of Arid Land Research Center, Tottori University (no. 28C2015).

Edited by: Jianping Huang

Reviewed by: two anonymous referees

\section{References}

Amato, P., Parazols, M., Sancelme, M., Mailhot, G., Laj, P., and Delort, A. M.: An important oceanic source of micro-organisms for cloud water at the Puy de Dôme (France), Atmos. Environ., 41, 8253-8263, 2007.

Atkinson, J. D., Murray, B. J., Woodhouse, M. T., Whale, T. F., Baustian, K. J., Carslaw, K. S., Dobbie, S., O’Sullivan, D., and Malkin, T. L.: The importance of feldspar for ice nucleation by mineral dust in mixed-phase clouds, Nature, 498, 355-358, 2013.

Bottos, E. M., Woo, A. C., Zawar-Reza, P., Pointing, S. B., and Cary, S. C.: Airborne Bacterial populations above desert soils of the McMurdo Dry Valleys, Antarctica, Microb. Ecol., 67, 120-128, 2014.

Bowers, R. M., McLetchie, S., Knight, R., and Fierer, N.: Spatial variability in airborne bacterial communities across land-use types and their relationship to the bacterial communities of potential source environments, ISME J., 5, 601-612, 2011.

Bowers, R. M., McCubbinb, I. B., Hallar, A. G., and Fierera, N.: Seasonal variability in airborne bacterial communities at a highelevation site, Atmos. Environ., 50, 41-49, 2012.

Brodie, E. L., DeSantis, T. Z., Parker, J. P. M., Zubietta, I. X., Piceno, Y. M., and Andersen, G. L.: Urban aerosols harbor diverse and dynamic bacterial populations, P. Natl. Acad. Sci. USA, 104, 299-304, 2007.

Brown, J. K. M. and Hovmøller, M. S.: Aerial dispersal of pathogens on the global and continental scales and its impact on plant disease, Science, 297, 537-541, 2002.

Cao, C., Jiang, W., Wang, B., Fang, J., Lang, J., Tian, G., Jiang, J., and Zhu, T. F.: Inhalable microorganisms in Beijing's $\mathrm{PM}_{2.5}$ and $\mathrm{PM}_{10}$ pollutants during a severe smog event, Environ. Sci. Technol., 48, 1499-1507, 2014.

Caporaso, J. G., Kuczynski, J., Stombaugh, J., Bittinger, K., Bushman, F. D., Costello, E. K., Fierer, N., Peña, A. G., Goodrich, J. K., Gordon, J. I., Huttley, G. A., Kelley, S. T., Knights, D., Koenig, J. E., Ley, R. E., Lozupone, C. A., McDonald, D., Muegge, B. D., Pirrung, M., Reeder, J., Sevinsky, J. R., Turnbaugh, P. J., Walters, W. A., Widmann, J., Yatsunenko, T., Zaneveld, J., and Knight, R.: QIIME allows analysis of highthroughput community sequencing data, Nat. Methods, 7, 335336, 2010.

Caporaso, J. G., Lauber, C. L., Walters, W. A., Berg-Lyons, D., Lozupone, C. A., Turnbaugh, P. J., Fierer, N., and Knight, R.: Global patterns of $16 \mathrm{~S}$ rRNA diversity at a depth of millions of sequences per sample, P. Natl. Acad. Sci. USA, 108, 4516-4522, 2011.

Cavicchioli, R., Ostrowski, M., Fegatella, F., Goodchild, A., and Guixa-Boixereu, N.: Life under nutrient limitation in oligotrophic marine environments: an eco/physiological perspective of Sphingopyxis alaskensis (formerly Sphingomonas alaskensis), Microb. Ecol., 45, 203-217, 2003.

Choi, D. H. and Noh, J. H.: Phylogenetic diversity of Synechococcus strains isolated from the East China Sea and the East Sea, FEMS Microbiol. Ecol., 69, 439-448, 2009.

Chung, Y. S. and Kim, H. S.: Observations of massive-air pollution transport and associated air quality in the Yellow Sea region, Air Qual. Atmos. Health, 1, 69-70, 2008.

Creamean, J. M., Suski, K. J., Rosenfeld, D., Cazorla, A., DeMott, P. J., Sullivan, R. C., White, A. B., Ralph, F. M., Minnis, P., Comstock, J. M., and Tomlinson, J. M.: Dust and biological aerosols 
from the Sahara and Asia influence precipitation in the western U.S., Science, 339, 1572-1578, 2013.

DeLeon-Rodriguez, N., Lathem, T. L., Rodriguez-R, L. M., Barazesh, J. M., Anderson, B. E., Beyersdorf, A. J., Ziemba, L. D., Bergin, M., Nenes, A., and Konstantinidis, K. T.: Microbiome of the upper troposphere: Species composition and prevalence, effects of tropical storms, and atmospheric implications, P. Natl. Acad. Sci. USA, 110, 2575-2580, 2013.

Delort, A. M., Vaïtilingom, M., Amato, P., Sancelme, M., Parazols, M., Mailhot, G., Laj, P., and Deguillaume, L.: A short overview of the microbial population in clouds: Potential roles in atmospheric chemistry and nucleation processes, Atmos. Res., 98, 249-260, 2010.

Edgar, R. C.: UPARSE: highly accurate OTU sequences from microbial amplicon reads, Nat. Methods, 10, 996-998, 2013.

Fahlgren, C., Hagström, A., Nilsson, D., and Zweifel, U. L.: Annual variations in the diversity, viability, and origin of airborne bacteria, Appl. Environ. Microbiol., 76, 3015-3025, 2010.

Fierer, N. and Lennon, J. T.: The generation and maintenance of diversity in microbial communities, American J. Botany, 98, 439448, 2011

Fu, P., Zhuang, G., Sun, Y., Wang, Q., Chen, J., Ren, L. Yang, F., Wang, Z., Pan, X., Li, X., and Kawamura, K.: Molecular markers of biomass burning, fungal spores and biogenic SOA in the Taklimakan desert aerosols, Atmos. Environ., 130, 64-73, 2016.

Fürnkranz, M., Wanek, W., Richter, A., Abell, G., Rasche, F., and Sessitsch, A.: Nitrogen fixation by phyllosphere bacteria associated with higher plants and their colonizing epiphytes of a tropical lowland rainforest of Costa Rica, ISME J., 2, 561-570, 2008.

Gorbushina, A. A., Kort, R., Schulte, A., Lazarus, D., Schnetger, B., Brumsack, H. J., Broughton, W. J., and Favet, J.: Life in Darwin's dust: intercontinental transport and survival of microbes in the nineteenth century, Environ. Microbiol., 9, 2911-2922, 2007.

Griffin, D. W.: Atmospheric movement of microorganisms in clouds of desert dust and implications for human health, Clin. Microbiol. Rev., 20, 459-477, 2007.

Guan, X., Huang, J., Zhang, Y., Xie, Y., and Liu, J.: The relationship between anthropogenic dust and population over global semi-arid regions, Atmos. Chem. Phys., 16, 5159-5169, https://doi.org/10.5194/acp-16-5159-2016, 2016.

Hallett, J. and Mossop, S. C.: Production of secondary ice particles during the riming process, Nature, 249, 26-28, 1974.

Hara, K. and Zhang, D.: Bacterial abundance and viability in longrange transported dust, Atmos. Environ., 47, 20-25, 2012.

Hara, K., Maki, T., Kakikawa, M., Kobayashi, F., and Matsuki, A.: Effects of different temperature treatments on biological ice, Atmos. Environ., 140, 415-419, 2016 a.

Hara, K., Maki, T., Kobayashi, F., Kakikawa, M., Wada, M., and Matsuki, A.: Variations of ice nuclei concentration induced by rain and snowfall within a local forested site in Japan, Atmos. Environ., 127, 1-5, 2016b.

Hoose, C. and Möhler, O.: Heterogeneous ice nucleation on atmospheric aerosols: a review of results from laboratory experiments, Atmos. Chem. Phys., 12, 9817-9854, https://doi.org/10.5194/acp-12-9817-2012, 2012.

Hua, N. P., Kobayashi, F., Iwasaka, Y., Shi, G. Y., and Naganuma, T.: Detailed identification of desert-originated bacteria carried by Asian dust storms to Japan, Aerobiologia, 23, 291-298, 2007.
Huang, J. P., Liu, J. J., Chen, B., and Nasiri, S. L.: Detection of anthropogenic dust using CALIPSO lidar measurements, Atmos. Chem. Phys., 15, 11653-11665, https://doi.org/10.5194/acp-1511653-2015, 2015a.

Huang, Z., Huang, J., Hayasaka, T., Wang, S., Zhou, T., and Jin, H.: Short-cut transport path for Asian dust directly to the Arctic: a case study, Environ. Res. Lett., 10, 114018, https://doi.org/10.1088/1748-9326/10/11/114018, 2015b.

Ichinose, T., Nishikawa, M., Takano, H., Sera, N., Sadakane, K., Mori, I., Yanagisawa, R., Oda, T., Tamura, H., Hiyoshi, K., Quan, H., Tomura, S., and Shibamoto, T.: Pulmonary toxicity induced by intratracheal instillation of Asian yellow dust (Kosa) in mice, Regul. Toxico. Pharm., 20, 48-56, 2005.

Iwasaka, Y., Yamato, M., Imasu, R., and Ono, A.: The transport of Asia dust (KOSA) particles; importance of weak KOSA events on the geochemical cycle of soil particles, Tellus B, 40, 494-503, 1988.

Iwasaka, Y., Shi, G. Y., Yamada, M., Kobayashi, F., Kakikawa, M., Maki, T., Chen, B., Tobo, Y., and Hong, C.: Mixture of Kosa (Asian dust) and bioaerosols detected in the atmosphere over the Kosa particles source regions with balloon-borne measurements: possibility of long-range transport, Air. Qual. Atmos. Health., 2, 29-38, 2009.

Jaenicke, R.: Abundance of cellular material and proteins in the atmosphere, Science, 308, 73, https://doi.org/10.1126/science.1106335, 2005.

Jeon, E. M., Kim, H. J., Jung, K., Kim, J. H., Kim, M. Y., Kim, Y. P., and Ka, J. O.: Impact of Asian dust events on airborne bacterial community assessed by molecular analyses, Atmos. Environ., 45, 4313-4321, 2011.

Joly, M., Attard, E., Sancelme, M., Deguillaume, L., Guilbaud, C., Morris, C. E., Amato, P., and Delort, A. M.: Ice nucleation activity of bacteria isolated from cloud water, Atmos. Environ., 70, 392-400, 2013.

Khan, Z. and Doty, S. L.: Characterization of bacterial endophytes of sweet potato plants, Plant Soil, 322, 197-207, 2009.

Kobayashi, F., Iwata, K., Maki, T., Kakikawa, M., Higashi, T., Yamada, M., Ichinose, T., and Iwasaka, Y.: Evaluation of the toxicity of a Kosa (Asian duststorm) event from view of food poisoning: observation of Kosa cloud behavior and real-time PCR analyses of Kosa bioaerosols during May 2011 in Kanazawa, Japan, Air Qual. Atmos. Health, 9, 3-14, 2015.

Kourtev, P. S., Hill, K. A., Shepson, P. B., and Konopka A.: Atmospheric cloud water contains a diverse bacterial community, Atmos. Environ., 45, 5399-5405, 2011.

Lang-Yona, N., Lehahn, Y., Herut, B., Burshtein, N., and Rudich, Y.: Marine aerosol as a possible source for endotoxins in coastal areas, Sci. Total Environ., 499, 311-318, 2014.

Latifi, A., Ruiz, M., and Zhang, C. C.: Oxidative stress in cyanobacteria, FEMS Microbiol. Rev., 33, 258-278, 2009.

Liu, B., Ichinose, T., He, M., Kobayashi, N., Maki, T., Yoshida, S., Yoshida, Y., Arashidani, K., Nishikawa, M., Takano, H., Sun, G., and Shibamoto, T.: Lung inflammation by fungus, Bjerkandera adusta isolated from Asian sand dust (ASD) aerosol and enhancement of ovalbumin-induced lung eosinophilia by ASD and the fungus in mice, Allergy Asthma Clin. Immunol., 10, 10, https://doi.org/10.1186/1710-1492-10-10, 2014.

Maki, T., Susuki, S., Kobayashi, F., Kakikawa, M., Yamada, M., Higashi, T., Chen, B., Shi, G., Hong, C., Tobo, Y., Hasegawa, H., 
Ueda, K., and Iwasaka, Y.: Phylogenetic diversity and vertical distribution of a halobacterial community in the atmosphere of an Asian dust (KOSA) source region, Dunhuang City, Air. Qual. Atmos. Health, 1, 81-89, 2008.

Maki, T., Susuki, S., Kobayashi, F., Kakikawa, M., Tobo, Y., Yamada, M., Higashi, T., Matsuki, A., Hong, C., Hasegawa, H., and Iwasaka, Y.: Phylogenetic analysis of atmospheric halotolerant bacterial communities at high altitude in an Asian dust (KOSA) arrival region, Suzu City, Sci. Total Environ., 408, 4556-4562, 2010.

Maki, T., Kakikawa, M., Kobayashi, F., Yamada, M., Matsuki, A., Hasegawa, H., and Iwasaka, Y.: Assessment of composition and origin of airborne bacteria in the free troposphere over Japan, Atmos. Environ., 74, 73-82, 2013.

Maki, T., Puspitasari, F., Hara, K., Yamada, M., Kobayashi, F., Hasegawa, H., and Iwasaka, Y.: Variations in the structure of airborne bacterial communities in a downwind area during an Asian dust (Kosa) event, Sci. Total Environ., 488-489, 75-84, 2014.

Maki, T., Hara, K., Kobayashi, F., Kurosaki, Y., Kakikawa, M., Matsuki, A., Bin, C., Shi, G., Hasegawa, H., and Iwasaka, Y.: Vertical distribution of airborne bacterial communities in an Asian-dust downwind area, Noto Peninsula, Atmos. Environ., 119, 282-293, 2015.

Maki, T., Kurosaki, Y., Onishi, K., Lee, K. C., Pointing, S. B., Jugder, D., Yamanaka, N., Hasegawa, H., and Shinoda, M.: Variations in the structure of airborne bacterial communities in Tsogt-Ovoo of Gobi Desert area during dust events, Air Qual. Atmos. Health., 10, 249-260, https://doi.org/10.1007/s11869-0160430-3, 2016.

Mantelin, S., Fischer-Le Saux, M., Zakhia, F., Béna, G., Bonneau, S., Jeder, H., Lajudie, P., and Cleyet-Marel, J. C.: Emended description of the genus Phyllobacterium and description of four novel species associated with plant roots: Phyllobacterium bourgognense sp. nov., Phyllobacterium ifriqiyense sp. nov., Phyllobacterium leguminum sp. nov. and Phyllobacterium brassicacearum sp. nov., Int. J Syst. Evol. Microbiol., 56, 827-839, 2006.

Matulova, M., Husarova, S., Capek, P., Sancelme, M., and Delort, A. M.: Biotransformation of various saccharides and production of exopolymeric substances by cloud-borne Bacillus sp. 3B6, Environ. Sci. Technol., 48, 14238-14247, 2014.

Mazar, Y., Cytryn, E., Erel, Y., and Rudich, Y.: Effect of dust storms on the atmospheric microbiome in the Eastern Mediterranean, Environ. Sci. Technol., 50, 4194-4202, 2016.

McDonald, D., Price, M. N., Goodrich, J., Nawrocki, E. P., DeSantis, T. Z., Probst, A., Andersen, G. L., Knight, R., and Hugenholtz, P.: An improved Greengenes taxonomy with explicit ranks for ecological and evolutionary analyses of bacteria and archaea, ISME J., 6, 610-618, 2012.

Möhler, O., DeMott, P. J., Vali, G., and Levin, Z.: Microbiology and atmospheric processes: the role of biological particles in cloud physics, Biogeosciences, 4, 1059-1071, https://doi.org/10.5194/bg-4-1059-2007, 2007

Morris, C. E., Georgakopoulos, D. G., and Sands, D. C.: Ice nucleation active bacteria and their potential role in precipitation, $\mathrm{J}$. Phy. IV France, 121, 87-103, 2004.

Morris, C. E., Sands, D. C., Vinatzer, B. A., Glaux, C., Guilbaud, C., Buffière, A., Yan, S., Dominguez, H., and Thompson, B. M.:
The life history of the plant pathogen Pseudomonas syringae is linked to the water cycle, ISME J., 2, 321-334, 2008.

Morris, C. E., Sands, D. C., Bardin, M., Jaenicke, R., Vogel, B., Leyronas, C., Ariya, P. A., and Psenner, R.: Microbiology and atmospheric processes: research challenges concerning the impact of airborne micro-organisms on the atmosphere and climate, Biogeosciences, 8, 17-25, https://doi.org/10.5194/bg-8-17-2011, 2011.

Mortazavi, R., Attiya, S., and Ariya, P. A.: Arctic microbial and next-generation sequencing approach for bacteria in snow and frost flowers: selected identification, abundance and freezing nucleation, Atmos. Chem. Phys., 15, 6183-6204, https://doi.org/10.5194/acp-15-6183-2015, 2015.

Mostajir, B., Dolan, J. R., and Rassoulzadegan, F.: A simple method for the quantification of a class of labile marine pico- and nanosized detritus: DAPI Yellow Particles (DYP), Aquat. Microb. Ecol., 9, 259-266, 1995.

Murray, B. J., O’Sullivan, D., Atkinson, J. D., and Webb, M. E.: Ice nucleation by particles immersed in supercooled cloud droplets, Chem. Soc. Rev., 41, 6519-6554, 2012.

Newton, R. J., Jones, S. E., Eiler, A., McMahon, K. D., and Bertilsson, S.: A guide to the natural history of freshwater lake bacteria, Microbiol. Mol. Biol. Rev., 75, 14-49, 2011.

Nicholson, W. L., Munakata, N., Horneck, G., Melosh, H. J., and Setlow, P.: Resistance of Bacillus endospores to extreme terrestrial and extraterrestrial environments, Microbiol. Mol. Biol. Rev., 64, 548-572, 2000.

Nold, S. C. and Zwart, G.: Patterns and governing forces in aquatic microbial communities, Aquat. Ecol., 32, 17-35, 1998.

Pointing, S. B. and Belnap, J.: Disturbance to desert soil ecosystems contributes to dust-mediated impacts at regional scales, Biodivers. Conserv., 24, 1659-1667, 2014.

Polymenakou, P. N., Mandalakis, M., Stephanou, E. G., and Tselepides, A.: Particle size distribution of airborne microorganisms and pathogens during an intense African dust event in the Eastern Mediterranean, Environ. Health Perspect., 116, 292-296, 2008.

Pratt, K. A., DeMott, P. J., French, J. R., Wang, Z., Westphal, D. L., Heymsfield, A. J., Twohy, C. H., Prenni, A. J., and Prather, K. A.: In situ detection of biological particles in cloud ice-crystals, Nat. Geosci., 2, 398-401, 2009.

Puspitasari, F., Maki, T., Shi, G., Bin, C., Kobayashi, F., Hasegawa, H., and Iwasaka, Y.: Phylogenetic analysis of bacterial species compositions in sand dunes and dust aerosol in an Asian dust source area, the Taklimakan Desert, Air Qual. Atmos. Health., 9, 631-644, 2015.

Redford, A. J., Bowers, R. M., Knight, R., Linhart, Y., and Fierer, N.: The ecology of the phyllosphere: geographic and phylogenetic variability in the distribution of bacteria on tree leaves, Environ. Microbiol., 12, 2885-2893, 2010.

Rodó, X., Ballester, J., Cayan, D., Melish, M. E., Nakamura, Y., Uehara, R., and Burns, J. C.: Association of Kawasaki disease with tropospheric wind patterns, Sci. Reports, 1, 152, https://doi.org/10.1038/srep00152, 2011.

Russell, W. C., Newman, C., and Williamson, D. H.: A simple cytochemical technique for demonstration of DNA in cells infected with mycoplasms and viruses, Nature, 253, 461-462, 1974.

Schloss, P. D., Westcott, S. L., Ryabin, T., Hall, J. R., Hartmann, M., Hollister, E. B., Lesniewski, R. A., Oakley, B. B., Parks, D. H., Robinson, C. J., Sahl, J. W., Stres, B., Thallinger, G. G., Horn, 
D. J. V., and Weber, C. F.: Introducing mothur: open-source, platform-independent, community-supported software for describing and comparing microbial communities, Appl. Environ. Microbiol., 75, 7537-7541, 2009.

Sheridan, P. P., Miteva, V. I., and Brenchley, J. E.: Phylogenetic analysis of anaerobic psychrophilic enrichment cultures obtained from a Greenland glacier ice core, Appl. Environ. Microbiol., 69, 2153-2160, 2003.

Smith, D. J., Timonen, H. J., Jaffe, D. A., Griffin, D. W., Birmele, M. N., Warda, P. P. D., and Roberts, M. S.: Intercontinental dispersal of bacteria and archaea by transpacific winds, Appl. Environl. Microbiol., 79, 1134-1139, 2013.

Sugimoto, N., Huang, Z., Nishizawa, T., Matsui, I., and Tatarov, B.: Fluorescence from atmospheric aerosols observed with a multichannel lidar spectrometer, Opt. Express, 20, 20800-20807, 2012.

Tanaka, D., Tokuyama, Y., Terada, Y., Kunimochi, K., Mizumaki, C., Tamura, S., Wakabayashi, M., Aoki, K., Shimada, W., Tanaka, H., and Nakamura, S.: Bacterial communities in Asian dust-containing snow layers on Mt. Tateyama, Japan, Bull. Glaciological. Res., 29, 31-39, 2011.

Temkiv, T. Š., Kai F., Bjarne, M. H., Niels, W. N., and Ulrich, G. K.: The microbial diversity of a storm cloud as assessed by hailstones, FEMS Microbial. Ecol., 81, 684-695, 2012.

Turnbaugh, P. J., Biomolecules, S. B. D., and Roscoff, F.: Environmental and gut bacteroidetes: the food connection, Front Microbiol., 2, 93-111, 2011.
Twohy, C. H., McMeeking, G. R., DeMott, P. J., McCluskey, C. S., Hill, T. C. J., Burrows, S. M., Kulkarni, G. R., Tanarhte, M., Kafle, D. N., and Toohey, D. W.: Abundance of fluorescent biological aerosol particles at temperatures conducive to the formation of mixed-phase and cirrus clouds, Atmos. Chem. Phys., 16, 8205-8225, https://doi.org/10.5194/acp-16-8205-2016, 2016.

Vaïtilingom, M., Attard, E., Gaiani, N., Sancelme, M., Deguillaume, L., Flossmann, A. I., Amato, P., and Delort, A. M.: Long-term features of cloud microbiology at the puy de Dôme (France), Atmos. Environ., 56, 88-100, 2012.

Wang, Q., Garrity, G. M., Tiedje, J. M., and Cole, J. R.: Naive Bayesian classifier for rapid assignment of rRNA sequences into the new bacterial taxonomy, Appl. Environ. Microbiol., 73, 5261-5267, 2007.

Watanabe, K., Yachi, C., Nishibe, M., Michigami, S., Saito, Y., Eda, N., Yamazaki, N., and Hirai, T.: Measurements of atmospheric hydroperoxides over a rural site in central Japan during summers using a helicopter, Atmos. Environ., 146, 174-182, 2016.

Wei, K., Zou, Z., Zheng, Y., Li, J., Shen, F., Wu, C. Y., Hua, M., and Yao, M.: Ambient bioaerosol particle dynamics observed during haze and sunny days in Beijing, Sci. Total Environ., 550, 751759, 2016.

Woo, A. C., Brar, M. S., Chan, Y., Lau, M. C., Leung, F. C., Scott, J. A., Vrijmoed, L. P., Zawar-Reza P., and Pointing, S. B.: Temporal variation in airborne microbial populations and microbiallyderived allergens in a tropical urban landscape, Atmos. Environ. 74, 291-300, 2013. 